\title{
Racializing Mexican Immigrants in Iowa's Early Mexican Communities
}

\author{
OMAR VALERIO-JIMÉNEZ
}

IN THE MID-1920s, a U.S. Department of Labor (USDL) official interviewed several local residents of Mason City, Iowa, for a government report on Mexican immigrants in the Midwest. The report identified each of the interviewed white, native-born Iowans by name and occupation and included lengthy passages with their views on immigrants, Americanization efforts, and social relations between immigrants and the dominant society. Among the interviewees were education officials, charity workers, and company managers. Also interviewed were Mexican sugar beet workers, who were not named individually but rather identified as a group of "Mexican beet workers." The omission of individual names contributed to Mexicans' racialization by the USDL official, who undoubtedly was following local convention that treated these workers as an undifferentiated group of "racial others" without individual identities. ${ }^{1}$

1. Racialization is a historically specific process in which people create hierarchical categories based on perceived differences in embodied physical characteristics. This racialization often serves to reinforce the unequal distribution of power and to "explain" the supposed superiority of one group over another. Michael Omi and Howard Winant add that racialization is "the extension of racial meaning to a previously racially unclassified relationship, social practice, or group." For a discussion of racialization processes in different contexts, see Michael Omi and Howard Winant, Racial Formation in the United States: From the 1960s to the 1990s, 3rd ed. (New York, 2015), 13, 111, 142; Tomás Almaguer, Racial Fault Lines: The Historical Origins of White Supremacy in California (Berkeley, CA, 1994), 3, 4-7, 25-26; and Pablo Mitchell, Coyote Nation: Sexuality, Race, and Conquest in Modernizing New Mexico, 1880-1920 (Chicago, 2005), 20-21, 62-63, 78-79.

THE ANNALS OF IOWA 74 (Winter 2016). (C) State Historical Society of Iowa, 2016. 
Totaling only eight sentences, the summary of the interviewer's interactions with the Mexican workers was the shortest part of the Mason City report. Yet those brief remarks were revealing. Among the 25 families of Mexican immigrants who lived in a "company colony near the factory," four were Protestant, which revealed a degree of acculturation to U.S. society. Several of the families had previously worked in various states across the United States, confirming their translocal connections. The most telling sentences contained the immigrants' views of racial relations: "All report that there is no distinction here but there is in Texas. 'Here one God, in Texas, three, white, black, and Mexican.' " 2 These immigrants, like many others in the Midwest, had previously lived in Texas and believed that racial relations were better in Iowa than in Texas. More specifically, the last line (which was presumably a quote) alluded to distinct religious services for white, African American, and Mexican churchgoers in Texas, while hinting that these three groups attended non-segregated religious services in Iowa. ${ }^{3}$

This article describes the experiences of Mexican immigrants in several communities in eastern and north-central Iowa during the first three decades of the twentieth century. I examine these immigrants' employment and the communities they established, as well as the factors that led them to choose Iowa as a destination. Mexican immigrants were attracted to Iowa by various economic opportunities and chose to stay in the state because of the availability of steady work, their social ties to family and friends, and the state's relatively lower racial tensions. In addition to adapting to the state's labor restrictions, Mexicans also adjusted to their racialization as non-white by Iowa residents.

As elsewhere in the Midwest, Iowa's majority white population struggled to locate Mexicans within the ethnoracial order in the United States; Mexicans were simultaneously "non-white"

2. George T. Edson, "Iowa and Wisconsin," George T. Edson Field Reports, 1927, Paul S. Taylor Papers, BANC MSS 84/38c (microfilm 2414), Bancroft Library, University of California, Berkeley (hereafter cited as Edson Field Reports).

3. These immigrants might have been referring to attending Catholic church services with some southern and eastern European immigrants in Mason City. For other immigrants, this reference might have also alluded to attending Protestant church services with white Iowans, European immigrants, or African Americans. See the discussion of Lehigh Row later in this article. 
and "non-black" but also "foreign." 4 White Iowans placed Mexican immigrants in an in-between status, below recent European immigrants but above African Americans. Because their ethnoracial status was unstable, there was no single pattern of reception for Mexican immigrants in Iowa; it varied by locale and social context. In some towns, Mexicans were grouped with southern and eastern European immigrants, while in other communities they were classified with African Americans.

White Iowans' racial views were influenced by their reliance on what historian Natalia Molina calls "racial scripts," that is, "the ways in which we think, talk about, and act toward one racialized group based on our experiences with other groups whose race differs from our own." Molina argues that racial scripts are influenced by a variety of factors, including location, time period, power relations, material conditions, and specific issues. ${ }^{5}$ In early twentieth-century Iowa, the number of Mexican immigrants in a particular town and those immigrants' relations with European immigrants and African Americans influenced such racial scripts and shaped white residents' views of Mexicans.

The Midwest's demographic context not only influenced how white, native-born Iowans viewed Mexicans, but also shaped Mexican immigrants' opportunities for interethnic and interracial alliances. Because Mexicans did not have a longstanding presence in the Midwest (compared to the Southwest), white Iowans did not hold rigid views of Mexicans' ethnoracial status. Moreover, the low number of Mexican immigrants required some of them to ally with non-Mexicans on a daily basis, which was less common in the Southwest, where there were more Mexican immigrants. Throughout the state, Mexicans were more likely to live in the same neighborhoods as southern and eastern European immigrants than with African Americans. Their housing

4. For a similar discussion of Mexicans' in-between racial status in Chicago, see Lilia Fernandez, Brown in the Windy City: Mexicans and Puerto Ricans in Postwar Chicago (Chicago, 2012), 8-13, 16-17; Gabriela Arredondo, Mexican Chicago: Race, Identity, and Nation, 1916-39 (Urbana, IL, 2008), 38, 58-64; and Michael InnisJiménez, Steel Barrio: The Great Mexican Migration to South Chicago, 1915-1940 (New York, 2013), 26, 53, 71, 89, 94-97.

5. Natalia Molina, "The Power of Racial Scripts: What the History of Mexican Immigration Teaches Us about Relational Notions of Race," Latino Studies 8 (2010), 157. 
arrangements, in turn, influenced social and political relations with other minority and immigrant populations. While Mexican immigrants experienced less racial antagonism in Iowa than in Texas, discrimination was not absent in their lives.

TO UNDERSTAND the experience of Mexican Americans in the Midwest, scholars have offered various interpretive models. Some suggest that Mexican immigration shared similarities to European immigration. Historian Arturo Rosales argues against this analogy because Mexicans encountered more racial discrimination than their European American counterparts. According to Rosales, the experience of Mexicans in the Midwest differed from that in the Southwest for two principal reasons: Mexicans in the Midwest did not share a history of conquest, and their regional origins in Mexico were different. Unlike immigrants to the Southwest who originated in Mexico's northern border states, those moving to the Midwest were mostly from states in Mexico's interior. Another difference was that immigrants to the Southwest often had some cultural affinities with the local Mexican American population, while those moving to the Midwest were creating new communities with no prior history of Mexican American settlement. Historian Dennis Valdés identifies additional distinctions: Mexicans in the Midwest looked to Mexico rather than the Southwest as a homeland, and they were mainly an urban population. According to Valdés, to understand the experience of Mexicans in the Midwest, scholars should begin by assuming that the main cultural dichotomy in the Midwest is a black-white one rather than a Mexican-Anglo division. Furthermore, Mexicans have not had a long history within the cultural divisions of the Midwest; neither have they become part of the dominant European American culture. ${ }^{6}$

6. Francisco A. Rosales, "Mexicanos in Indiana Harbor during the 1920s: Prosperity and Depression," Revista Chicano-Riqueña 4 (1976), 88-98; Dennis Nodín Valdés, "Region, Nation, and World-System: Perspectives on Midwestern Chicana/o History," in Voices of a New Chicana/o History, ed. Refugio I. Rochín and Dennis N. Valdés (East Lansing, MI, 2000), 115-40; Juan R. García, Mexicans in the Midwest: 1900-1932 (Tucson, AZ, 1996), vii-viii; Dennis Nodín Valdés, "Historical Foundations of Latino Immigration and Community Formation in 20thCentury Michigan and the Midwest," in Immigration and Ethnic Communities: A Focus on Latinos, ed. Refugio I. Rochin (East Lansing, MI, 1996), 43. 
Several scholars suggest that the experience of Mexicans in the Midwest needs to be studied on its own and not necessarily compared to immigrants' experience in the Southwest.7 I agree that we need to study the development of midwestern communities, but I believe that it is useful to make comparisons, not just to the Southwest but also within the Midwest (rural communities, large urban centers, and small towns). Such comparisons illustrate the heterogeneity of the immigrant experience and, more importantly, help us understand the regional particularities that gave rise to diverse receptions from local European Americans, the immigrants' selective acculturation, and the distinct histories through which ethnic enclaves developed.

LATINOS' PRESENCE in Iowa dates to the 1880s, when Mexican immigrants began arriving to work in the state's railroad yards or in its agricultural fields, picking tomatoes and beets. Those laborers, however, were seasonal migrants who moved throughout the Midwest following harvests or working on temporary railroad maintenance projects. ${ }^{8}$ Initially, this temporary labor force consisted of men who had left their families in Mexico. Labor contractors recruited single men (or men without their families) as "sojourners" who would return to Mexico after the beet season or railroad track work ended. This recruitment strategy was designed to depress sojourners' wages and to ease white residents' fears that Mexicans would settle permanently near the fields. The practice of recruiting single men (or men without families) racialized Mexican immigrants as laborers who should not become permanent residents or U.S. citizens.

In the early 1920s, however, the Great Western Sugar Company and other companies, in an effort to promote more workforce stability, began recruiting families to work in the sugar beet fields. The companies undoubtedly understood that recruiting

7. Edward J. Escobar, "The Forging of a Community: The Latino Experience in Northwest Indiana," Latino Studies Journal 2 (1991), 38-57; Zaragosa Vargas, Proletarians of the North: A History of Mexican Industrial Workers in Detroit and the Midwest, 1917-1933 (Berkeley, CA, 1993); Fernandez, Brown in the Windy City; Arredondo, Mexican Chicago.

8. J. García, Conóceme en Iowa, cited in Teresa A. García, "Mexican Room: Public Schooling and the Children of Mexican Railroad Workers in Fort Madison, Iowa, 1923-1930" (Ph.D. diss., University of Iowa, 2008), 51. 
families meant that employers would obtain the additional labor of wives and children and that this labor would be underpaid or unpaid. Accustomed to practicing family labor, Mexicans were motivated by declining agricultural wages, forcing family members to labor in the fields. ${ }^{9}$

At approximately the same time, the Atchison, Topeka, and Santa Fe Railway Company (ATSF or Santa Fe) began encouraging Mexican immigrant track workers to bring their families to the United States. According to historian Jeffrey Garcilazo, that recruitment strategy was part of the Santa Fe's effort to implement scientific management techniques that promoted efficiency, productivity, and loyalty. By recruiting families, the ATSF sought to prevent track workers from easily leaving their jobs or engaging in unionization efforts. ${ }^{10}$

The recruitment of families led Mexican immigrants to establish permanent settlements. However, some southwestern and midwestern employers denied that reality and instead sought to assure local residents and federal officials that Mexicans would not remain in the United States because their "homing" instinct would motivate them to return to Mexico after the harvests. ${ }^{11}$

Iowa's low population of Mexicans (29) in the 1900 census was similar to that of other midwestern states in the first two decades of the twentieth century. ${ }^{12}$ The number of Mexicans swelled over

9. Dennis Nodín Valdés, "Settlers, Sojourners, and Proletarians: Social Formation in the Great Plains Sugar Beet Industry, 1890-1940," Great Plains Quarterly 10 (1990), 112-13; George T. Edson, "Mexicans in the North Central States," Perspectives in Mexican American Studies 2 (1989), 105, 107. In the 1920s industrial and agricultural employers throughout the Midwest initiated concerted recruitment efforts targeting Mexican immigrant workers. See Fernandez, Brown in the Windy City, 63-64; Innis-Jiménez, Steel Barrio, 34-35; Vargas, 25-26; and Jeffrey Marcos Garcilazo, Traqueros: Mexican Railroad Workers in the United States, 1870 to 1930 (Denton, TX, 2012), 48, 117.

10. Garcilazo, Traqueros, 116-18.

11. Kathleen Mapes, Sweet Tyranny: Migrant Labor, Industrial Agriculture, and Imperial Politics (Urbana and Champaign, IL, 2009), 148-49; David G. Gutiérrez, Walls and Mirrors: Mexican Americans, Mexican Immigrants, and the Politics of Ethnicity (Berkeley, CA, 1995), 49.

12. Their total numbers were actually likely higher because the 1900 census counted only residents who were born in Mexico, and excluded those born in the United States. Another likely reason for an undercount was immigrants' transitory status as workers who often supplemented industrial jobs with seasonal employment in agriculture. García, Mexicans in the Midwest, 18, 26-27. 
MAP

IOWA CITIES WITH SIGNIFICANT MEXICAN IMMIGRANT

POPULATION BEFORE 1940

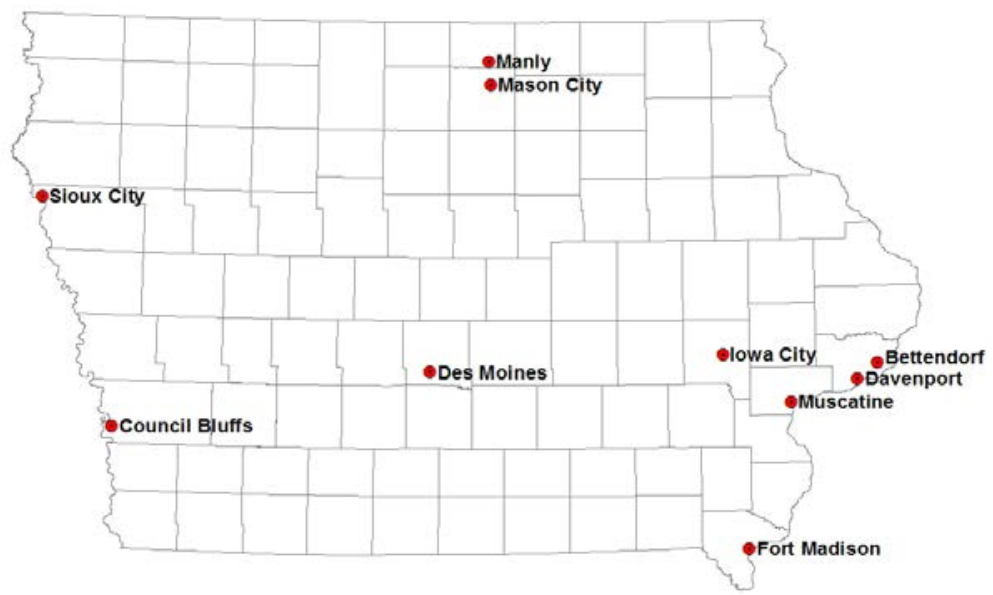

the next two decades as the turmoil of the Mexican Revolution (1910-1920) pushed them out of Mexico and increasing employment opportunities created by the United States' entry into World War I pulled them north. By 1910, more than 500 Mexicans lived in the state, and by 1920, the total reached 2,560.13

Other push and pull factors also partly explain Mexican migration to Iowa. The first arrivals had been pushed out of Mexico during the late nineteenth century by Mexican dictator Porfirio Díaz's land policies, which consolidated land among wealthy hacendados, and by the nation's early industrialization, which displaced skilled artisans. The start of the Mexican Revolution fueled additional outmigration by those seeking refuge from the war's violence and turmoil. ${ }^{14}$ Pulling Mexican immigrants to Iowa were employment opportunities promoted by labor contractors for the state's railroads and agricultural employers, and subsequently for foundries and cement factories. Mexican immigrants filled a labor need created by the decrease in the availability

13. García, “Mexican Room,” 51; Janet Weaver, “From Barrio to 'Boicoteo!': The Emergence of Mexican American Activism in Davenport, 1917-1970," Annals of Iowa 68 (2009), 217.

14. Gutiérrez, Walls and Mirrors, 44-45. 
of southern and eastern European immigrants, who were subject to quotas beginning in the 1920s. Additionally, some European immigrants left during World War I to serve in the military of their home countries. ${ }^{15}$

The activities of labor contractors and the gradual development of immigrant social networks better explain the laborers' migration to specific towns in Iowa. Mexican immigrants followed a familiar pattern of chain migration in which family and friends followed the first arrivals, who alerted those left in Mexico of the availability of jobs and of the expected living conditions. Recruited by the Lehigh Cement Company, brothers León and Miguel Vega arrived in Mason City, Iowa, from Salamanca, Guanajuato, in the early 1920s. After saving enough money for transportation costs, León sent for his family, who joined the Vega brothers as residents of Mason City's Lehigh Row community. ${ }^{16}$ The Vega family's origins fit the common pattern for Mexican immigrants to the Midwest, who came mostly from the central states of Guanajuato, Jalisco, and Michoacán. ${ }^{17}$

Other immigrants intended to travel elsewhere in the Midwest, but ended up in Iowa as a result of unscrupulous labor contractors who tricked them into signing contracts that the immigrants did not understand. Enganchistas (contractors) took advantage of immigrants' lack of English-language skills, according to Cesario Hernández. He described the contractors' schemes vividly. "A poor Mexican crosses the border and signs papers that the enganchista gives him, he cannot read English and does not know what he is signing. He is told that he will be shipped to where he wants, given free room and board, and fare back to

15. Edson, "Mexicans in the North Central States," 105; Kathleen Mapes, " 'A Special Class of Labor': Mexican (Im)Migrants, Immigration Debate, and Industrial Agriculture in the Rural Midwest," Labor: Studies in Working-Class History of the Americas 1 (2004), 66-67; Vargas, Proletarians of the North, 24-25; Jim Norris, North for the Harvest: Mexican Workers, Growers, and the Sugar Beet Industry (St. Paul, MN, 2009), 26-27.

16. "Lehigh Row Remembered," Des Moines Sunday Register, 4/29/1990, in Vega Family Papers, Mujeres Latinas Project, Iowa Women's Archives, University of Iowa Libraries, Iowa City (hereafter cited as MLP-IWA).

17. Vargas, Proletarians of the North, 21; Edson, "Mexicans in the North Central States," 100-101; Sebastián Alvarez interview, 2/3/1990, Iowa Labor History Oral Project, State Historical Society of Iowa, Iowa City (hereafter cited as ILHOP-SHSI); Weaver, “From Barrio to 'Boicoteo!'” 216. 
Mexico. They think they are going to work near Chicago and land some place in Iowa." 18 Not surprisingly, most Mexican immigrants to Iowa settled in towns that offered employment in sugar beets, railroad maintenance, or foundries.

As occurred throughout the Southwest, immigrant social networks funneled numerous immigrants to Iowa through chain migration and eventually made labor contractors superfluous. Initially drawn to the Midwest by temporary railroad and agricultural jobs, Mexicans gradually obtained more stable positions in railroad maintenance, packinghouses, and industrial factories. For those immigrants who had not taken part in employers' family recruitment strategy, the increased job stability enabled them to bring their wives and children and to provide better housing and educational opportunities for their families. Originally from the central Mexican states of Guanajuato and Zacatecas, the family of Inés García moved to Iowa on the advice of Magdaleno Sánchez, her mother's cousin. Sánchez, who had arrived from Mexico in the 1910s, lived in El Cometa, an ethnic enclave in Fort Madison, and worked for the Santa Fe railroad. He returned to Mexico to bring García's family and eventually secured railroad jobs for several of the family's adult males. ${ }^{19}$ Other family members arrived in Iowa after an extended process of step migration from Mexico into Texas, Oklahoma, and several midwestern states. ${ }^{20}$ As more families arrived, urban ethnic enclaves developed. Some were quite ethnically diverse while others remained mostly Mexican.

By the eve of the Great Depression, Iowa's Mexican population had grown to approximately 2,720. The population was distributed among four principal regions, according to George T. Edson, a Department of Labor official who toured the Midwest in the late 1920s to prepare a report on labor conditions. While in the state, Edson estimated its Mexican population by visiting ethnic enclaves, speaking with immigrant employers, and examining reports prepared by local agencies. His totals undercounted the number of immigrants because he failed to visit several towns

18. Cesario Hernández, quoted in Mapes, "A Special Class of Labor," 78.

19. Inés García interview, 11/7/1999, MLP-IWA.

20. García, Mexicans in the Midwest, 21-24; Dennis Nodín Valdés, Al Norte: Agricultural Workers in the Great Lakes Region, 1917-1970 (Austin, TX, 1991), 10-18. 


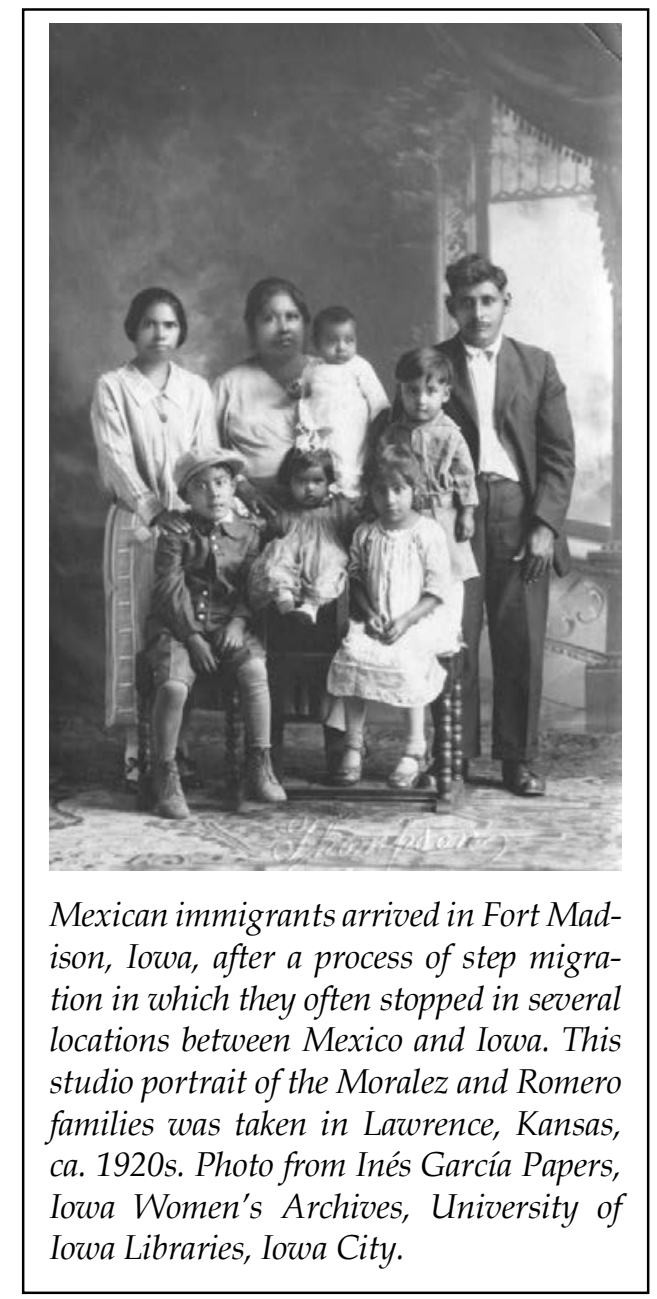

with Mexican populations (such as Iowa City) and because his survey occurred during the winter before seasonal migration brought additional immigrants to work in agriculture and railroad maintenance in the spring and summer months. The state's central region, including Des Moines and Valley Junction, had the smallest numbers at 471 , followed by the north central region with 544 in Manly and Mason City. At least 650 Mexicans lived in the west and northwest region (Council Bluffs and Sioux City), while three eastern towns (Bettendorf, Davenport, and Fort Mad- 
ison) were home to the largest concentration of Mexicans $(1,055)$ (see map). ${ }^{21}$

Employers provided free or rental housing for Mexican immigrants because they, like U.S. government officials, racialized Mexicans as temporary workers. Some midwestern agricultural employers had previously encouraged southern and eastern Europeans to become homeowners by offering them affordable houses, but they did not, according to historian Kathleen Mapes, extend those opportunities to Mexican immigrants, whom they viewed as only temporary laborers and not long-term residents or citizens. ${ }^{22}$ Immigrant housing consisted mostly of shacks, flats, cottages, and old railroad boxcars. There were few paved streets, so several enclaves, like Cook's Point in Davenport and El Cometa in Fort Madison, were prone to flooding. Living conditions were rudimentary, as most houses lacked electricity and running water. ${ }^{23}$ The Bettendorf Company, which manufactured railroad cars, owned the housing and land in Holy City, a mostly Mexican ethnic enclave in Bettendorf located along the Mississippi River. The company began recruiting Mexican immigrants for its foundry in 1918; by the mid-1920s, some of those laborers had settled in Holy City. 24

By the mid-1920s, the effects of employers' family recruiting strategies and the immigrants' decisions to settle their families in the state were evident in the composition of the Mexican immigrant population. Women and children made up 50-70 percent of the Mexican population in some towns. In Mason City, a third of the Mexican immigrants were sugar beet workers, and women and children made up close to 70 percent of the Mexican popu-

21. Edson's population estimates were close to the total from the state of Iowa's 1925 census, which listed 2,597 Mexican nationals residing in the state. Edson, "Mexicans in the North Central States," 107-8; García, "Mexican Room," 59-64; "Census of Iowa for the Year 1925," x, xli, from www.iowadatacenter.org/ Publications/iowa1925.pdf/view?searchterm=1925\%20census. In 1925 Mexicans represented 0.11 percent of the state's population of 2,419,927.

22. Mapes, Sweet Tyranny, 122-23.

23. Sebastián Alvarez interview; Weaver, "From Barrio to 'Boicoteo!'” 216-18; García, "Mexican Room," 71; Helen R. Karamitros, "Lehigh Row, An Ethnic Experience" (M.A. thesis, Mankato State University, 1998), 43-49.

24. Peter Vega interview; García, "Mexican Room," 63; Weaver, "From Barrio to 'Boicoteo!'” 218. 
lation. ${ }^{25}$ Throughout the Midwest, it was common for the sex ratios among Mexican immigrants to be skewed in industrial settings and more balanced in agricultural communities. In several midwestern cities, adult men composed 80 percent of the Mexican immigrant population. That ratio was a result of differing hiring practices between industrial and agricultural employers; the former recruited individual men while the latter tended to recruit families. Iowa's Mexican communities had a more balanced sex ratio than those in other states, even in the Midwest, because many immigrants participated in agricultural labor. During the winter of 1926-27, adult men made up from 57 to 65 percent of the adult Mexican immigrants in six communities surveyed by labor officials. Towns such as Mason City with a large agricultural base tended to have more even sex ratios than towns such as Fort Madison where most immigrants worked in industrial occupations. ${ }^{26}$

TO UNDERSTAND the racialization of Mexicans in Iowa, it is necessary to know the historical context in which previous immigrants labored in agriculture and subsequently left for other employment, creating a labor shortage that was filled by Mexicans. During the early twentieth century, Mexican immigrants gradually replaced European immigrant laborers in the Midwest's sugar beet industry as the latter became farmers or industrial laborers. Wage increases in industrial jobs and expanding employment opportunities in cities during World War I had combined to reduce the number of European immigrant agricultural workers in the region. Facing labor shortages, U.S. agricultural employers began viewing Mexico as a convenient labor source because of its proximity and abundance of workers willing to emigrate. Employers, who could easily recruit and transport workers from Mexico and back via the railroads, sought to guarantee that Mexicans did not become permanent local residents because white midwesterners (including Iowans) racialized Mexicans as "non-

25. Edson, "Mexicans in the North Central States," 107-8; García, "Mexican Room," 58, 61.

26. Dionicio Nodín Valdés, Barrios Norteños: St. Paul and Midwestern Mexican Communities in the Twentieth Century (Austin, TX, 2000), 52-53; García, "Mexican Room," 55. 


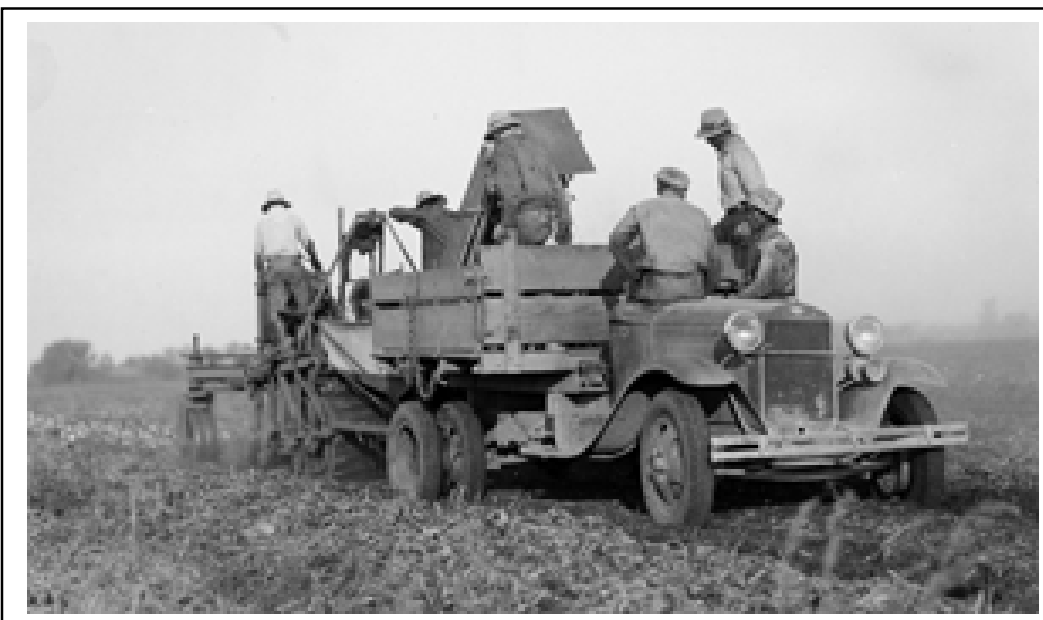

A group of farm workers and farmers ride on a truck near Mason City, ca. 1910-1920. Photo from Agricultural and Natural Resources Archive, Colorado State University, Archives and Special Collections, Fort Collins, Colorado.

whites" who were not welcomed as permanent community members. Agricultural employers also sought Mexicans because of their lack of political strength in the Midwest, which made them more susceptible to labor controls and exploitation.

Intent on hiring Mexican immigrants, agricultural employers successfully lobbied U.S. government officials for an exemption from the Immigration Act of 1917. ${ }^{27}$ In response to growers' requests, the U.S. Department of Labor waived the Immigration Act's head tax and literacy requirement for Mexicans. It also allowed for the temporary admission of Mexican laborers and their families for six months as contract agricultural laborers, restricted their employment to farm work, and stipulated that the laborers could not become U.S. citizens. According to historian Kathleen Mapes, the USDL thereby created a "form of racialized and nationalized labor" in a "unilateral guest worker program" that

27. Valdés, Al Norte, 8-10; Mapes, Sweet Tyranny, 123; Norris, North for the Harvest, 27; Camille Guerin-Gonzales, Mexican Workers and American Dreams: Immigration, Repatriation, and California Farm Labor, 1900-1939 (New Brunswick, NJ), 44. 
"defined Mexicans as workers but not as future neighbors or citizens." 28 The state's control over Mexican workers included the authority to imprison and deport laborers who were apprehended after deserting their contracts. The need for Mexican agricultural workers increased further in the 1920s with the passage of the so-called quota laws (1921 and 1924), which severely restricted the annual number of immigrants from southern and eastern Europe. To fill the resulting labor need, labor recruiters once again sought out Mexican immigrant workers by traveling to Texas and hiring those who had recently arrived there. ${ }^{29}$

In the Midwest, Mexican immigrant laborers did not become farmers because of their lack of capital, declining agricultural wages, and their pattern of circular migration. Earlier waves of European immigrant workers had purchased farms in Iowa, but no Mexicans had become farmers by the late 1920s. German immigrants had brought some capital that enabled them to purchase farms. Other European immigrants arrived in the Midwest at the turn of the century when agricultural wages had not yet declined precipitously. They were able to accumulate savings from their wages as agricultural laborers and eventually purchase land to become farmers. Still other immigrants moved into industrial occupations. In contrast, Mexican immigrants faced different obstacles and limited opportunities. Unlike earlier European immigrants, Mexican immigrants arrived with little or no capital. Although some Mexican sugar beet laborers expressed an interest in purchasing farms, none were able to own or even rent a farm. Declining wages were the principal factor. Mexican immigrants entered the sugar beet labor force during a period when wages were low after a period of sustained decline. Agricultural wages continued dropping throughout the 1920s and were too low for the laborers to save enough to buy farms or to

28. Mapes, Sweet Tyranny, 129-30, 142. In 1920 Iowa officials imprisoned some 40 Mexicans (including women and children) in the Polk County jail and subsequently deported them for deserting the beet fields of northern Iowa. Denison Review, 9/1/1920. Officials also deported Mexican immigrants who arrived in Fort Dodge but refused to work in the beet fields and sought work elsewhere. Marshalltown Evening Times-Republican, 7/27/1920.

29. Paul Spickard, Almost All Aliens: Immigration, Race, and Colonialism in American History and Identity (New York, 2007), 277-82; Valdés, Al Norte, 10. 
purchase equipment as tenant farmers. ${ }^{30}$ Seasonal wages for adult sugar beet workers in the upper Midwest declined from $\$ 280$ in 1920 to $\$ 160$ by the late 1920s. Subsequently, agricultural laborers witnessed their wages drop by half during the Great Depression of the 1930s. ${ }^{31}$ Even if they could afford to purchase farms in the Midwest, some Mexican immigrants chose not to do so because they intended to return to Mexico after the agricultural season. This pattern of circular migration led some immigrants to invest their meager savings to support their families back in Mexico or to purchase property there.

Iowa's industrial sector, especially railroad and meatpacking companies, provided additional employment opportunities for Mexican immigrants. In the first decade of the twentieth century, railroad companies began recruiting Mexican immigrant laborers to the Midwest for track maintenance and repair work, which became racialized as labor reserved for Mexicans or African Americans. This recruitment led to the establishment of the first Mexican settlements in the Midwest: boxcar communities on company property. Because railroad work was seasonal, these first labor migrants were mainly unaccompanied men.

Pioneering the use of international labor networks to recruit Mexicans, railroad companies in the late 1910s increased their recruitment efforts to meet wartime demands and to offset the decrease in the availability of European immigrants. Labor agents traveled into Mexico on railroads to enlist laborers, promising them work in the U.S. Southwest and later in the Midwest. ${ }^{32}$ Most Mexicans labored as maintenance workers for one of ten railroad companies and helped establish immigrant railroad communities in Council Bluffs and Des Moines in the western and central part of the state and in the eastern Iowa communities of Davenport, Bettendorf, and Fort Madison. The significant role of railroad employment for Mexican immigrant communities can be seen in the Quad Cities area, where about 75 percent of Mexican male laborers worked for the railroads. By the mid-1920s, railroad maintenance work had attracted Mexican immigrants to

30. W. H. Baird, Mason City, in Edson, "Iowa and Wisconsin," Edson Field Reports; Valdés, "Settlers, Sojourners, and Proletarians," 111-14.

31. Valdés, Al Norte, 18; Valdés, “Settlers, Sojourners, and Proletarians,” 114.

32. Valdés, Barrios Norteños, 25-28. 
new settlement areas in Sioux City, Manly, and Mason City. Mexican men found temporary employment as day laborers or on railroad track maintenance crews, but many railroad workers could count on only seven months of employment as companies instituted seasonal layoffs in winter. ${ }^{33}$

Some Mexican immigrants found employment opportunities outside agricultural labor and railroad work. Meatpacking companies such as Armour, Cudahy, and Swift provided employment for Mexicans in Sioux City, Council Bluffs, Mason City, and Des Moines. In Mason City and Des Moines, Mexicans worked in cement factories, foundries, and brick and tile factories, whereas Muscatine offered employment in button manufacturing and at the Heinz food processing plant. ${ }^{34} \mathrm{~A}$ few Mexicans established local businesses, such as grocery stores, pool halls, restaurants, and barbershops, in immigrant enclaves. Despite the prevalence and variety of work in the state, the population of Mexican immigrants in Iowa fluctuated sharply as a result of seasonal work in railroad maintenance and in the agricultural sector. ${ }^{35}$

Mexican women fulfilled critical labor roles within immigrant communities, and they, too, experienced a process of racialization as residents and laborers. They initially worked in agriculture and the informal economy, but they ultimately entered Iowa's industrial labor force. By the late 1920s, several Mexicanas were working at a meatpacking plant in Mason City, while others labored at a cement company in Valley Junction. ${ }^{36}$ Mostly, though, Mexican women performed agricultural labor as

33. Edson, "Mexicans in the North Central States," 105; Valdés, Barrios Norteños, 28-29, 81; García, "Mexican Room," 57-58; Frank Tobias Higbie, "Rural Work, Household Subsistence, and the North American Working Class: A View from the Midwest," International Labor and Working-Class History 65 (2004), 54-56.

34. Deborah Fink, Cutting into the Meatpacking Line: Workers and Change in the Rural Midwest (Chapel Hill, NC, 1998), 124-25; García, "Mexican Room," 56, 67; Micheal Hutchinson, "River of Steel, River of Sweat: Hispanic Community in Muscatine, Iowa" (M.A. thesis, University of Iowa, 1988), www.immigration-usa.com/new/ mexican_american.html.

35. George T. Edson, "Mexicans in Fort Madison, Iowa," Edson Field Reports; George T. Edson, "Mexicans in Davenport, Iowa, and Moline, Illinois," Edson Field Reports; Edson, "Mexicans in the North Central States," 112; García, "Mexican Room," 57.

36. George T. Edson, "Mexicans in Mason City, Iowa," Edson Field Reports; García, "Mexican Room,” 67. 
part of families employed in the sugar beet industry, and some eventually worked in industrial jobs. While men performed the blocking of sugar beets, women and children were responsible for weeding. Adult women also helped with hoeing and with the topping after the harvest. The labor of women and children was crucial because it allowed immigrant men to sign contracts with farmers for an amount of acreage that required a family (and not just one individual) to block and thin. ${ }^{37}$

White Iowans racialized Mexican immigrant women as "non-white" and, other than employing them in the fields as part of families, generally refused to hire them except as domestic workers. Because discriminatory practices limited opportunities for wage labor, Mexican women engaged in an informal economy, selling food, sewing, and performing domestic work for white, middle-class families. ${ }^{38}$ One resident of Fort Madison remembers her female relatives making extra money by selling homemade postcards. "My mom and my aunt Margarita used to make these beautiful postcards.... They used to embroider happy birthday or whatever the occasion was and they'd sell 'em." 39

As elsewhere in the United States, Mexican women in Iowa supplemented their family's income by operating boardinghouses as well as taking in laundry and doing ironing out of their homes. These services were needed by many of the communities' single men. In Davenport, for example, Gertrudes Veyna lived with her husband (both were Mexican immigrants) and an infant son in a rented house, which also housed five boarders (four Mexican immigrants and one Mexican American) in 1920.40 Commenting on such entrepreneurial women, Inés García recalls, "I know my godmother Romana used to take in washings for the men and wash their clothes, and mend 'em, and iron 'em. And they made a little money that way." 41

37. Edson, "Mexicans in the North Central States," 107-8.

38. Inés García interview, 11/7/1999, MLP-IWA; García, "Mexican Room," 100101; Luz María Gordillo, Mexican Women and the Other Side of Immigration (Austin, TX, 2010), 14, 107-8.

39. Garcilazo, Traqueros, 141; Inés García interview.

40. U.S. Bureau of the Census, Fourteenth Census of the United States: 1920, Population Schedule, Scott County, Iowa.

41. Inés García interview; Edson, “Mexicans in the North Central States,” 110. 


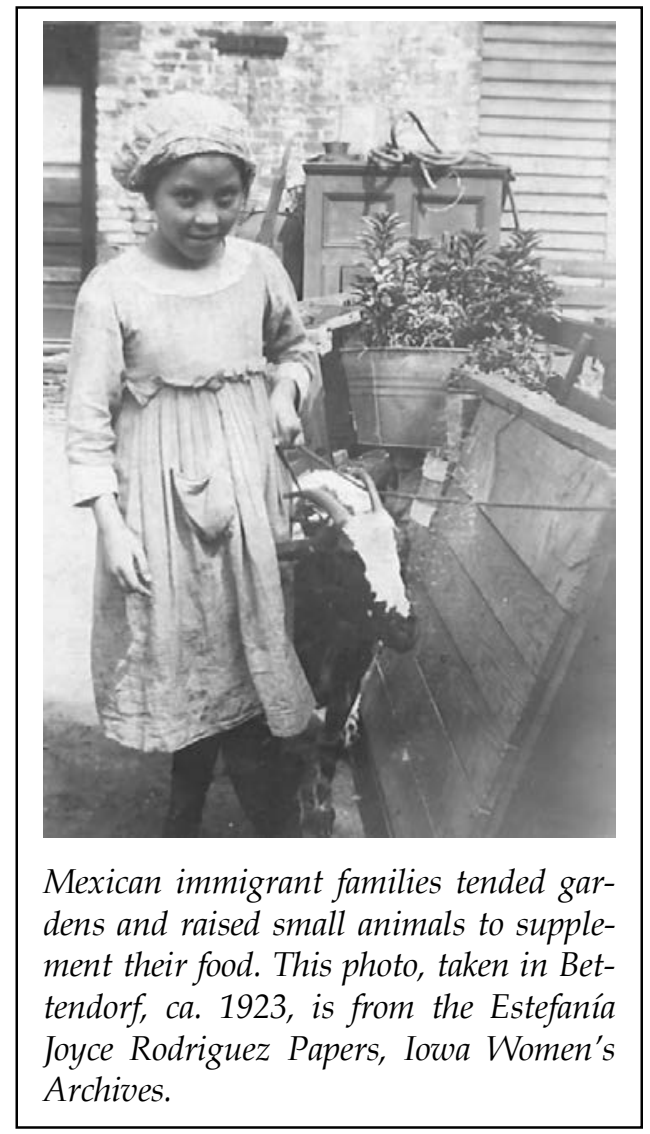

Mexican women also tended gardens on land provided by the railroad, cement, and sugar companies. They raised chickens and pigs and grew vegetables as well as herbs and spices used in Mexican dishes. Such activities replicated their customs in Mexico's rural communities. This homegrown food not only sustained the family but also provided a revenue source when surplus eggs, vegetables, and meat were sold. ${ }^{42}$ Beyond providing food, gardens were a source of pride for many boxcar residents who enjoyed

42. Estefanía Rodriguez interview, 8/11/2005, MLP-IWA; Benita Aguirre interview, 10/5/2005, MLP-IWA; Juanita Rodriguez and Ernest Rodriguez interview, 8/6/2005, MLP-IWA; Fink, Cutting into the Meatpacking Line, 124-25; Karamitros, "Lehigh Row," 49; García, "Mexican Room," 93; Garcilazo, Traqueros, $127-28$ 
growing flowers and potted plants to decorate their humble homes. ${ }^{43}$ By engaging in an informal economy or earning wages for industrial or agricultural labor, Mexican women gained a degree of autonomy and set an example for their daughters to emulate in seeking future employment. ${ }^{44}$

Mexican women also supplied unpaid reproductive labor that sustained Mexican communities and provided a measure of stability. As wives and daughters, they participated in a gendered division of domestic labor that assigned them the primary responsibility for childcare, food preparation, and other domestic chores. While these domestic roles were not remunerative and were usually unacknowledged by employers, they were essential for Mexican communities to flourish. Many daily household chores were time consuming and difficult as ethnic enclaves often lacked running water, electricity, and other modern conveniences. Several residents recalled the grueling daily task of carrying buckets of water for several blocks. Residents relied on a community faucet to obtain water for bathing, washing, and cooking. Others collected rainwater in barrels, which had to be cleaned often to avoid contamination. Women and children also had to collect firewood and coal for the pot-bellied stoves used for cooking and heating. In the winter, frigid temperatures compounded these tasks as the pipes to the faucets would occasionally freeze. Washing clothes was an arduous daily chore as school children and laborers owned few changes of clothes. ${ }^{45}$

Through friendships, women strengthened family ties to the larger Mexican immigrant community and sustained social networks that fueled chain migration. A male resident of Mason City recalled his mother's significant role as a midwife in a community with strong bonds. "My mother was a midwife. She delivered a lot of babies out there [at Lehigh Row]. Just imagine, the people never went to school. . . . But boy, did they know how to take care of each other and their family." 46

43. Garcilazo, Traqueros, 128; Benita Aguirre interview.

44. Garcilazo, Traqueros, 141-42.

45. María Mercedes Aguilera interview, 9/22/2005, MLP-IWA; Peter Vega interview; Benita Aguirre interview; Sebastián Alvarez interview; Dolores García interview, 9/22/2005, MLP-IWA.

46. Karamitros, "Lehigh Row," 60. 
Once women and children moved to Iowa to join immigrant men, families tended to stay in one location, and men opted to remain with the same employer. Cognizant of this stability and of the advantage of family labor, agricultural employers encouraged Mexican immigrant men to give up good jobs in the cities for agricultural labor in the Midwest by offering "free rent, a garden, and milk." 47 The reference to a garden acknowledged that women often accompanied Mexican men and that access to a garden appealed to families disappointed with urban life. Moreover, contractors admitted to lax enforcement of child labor laws because of their dependence on underage workers. To justify the practice, employers claimed that implementing child labor laws would cause Mexican immigrants to leave agricultural work because their families counted on their children's contribution to the family's labor. ${ }^{48}$

Besides following other family members to Iowa, various economic and social factors attracted Mexican immigrants to Iowa and elsewhere in the Midwest. Jobs were the main attraction, but the prospect of regular, long-term employment with the same employer led some immigrants to settle in Iowa. Regular employment allowed them to avoid constant migration across the Midwest in search of jobs, and to accommodate families who would not have to endure the frequent moves. ${ }^{49}$ Because sugar beet labor was seasonal, paid low wages, and subjected workers to harsh conditions, it was seen as the least desirable work; few laborers returned to it if they had other employment opportunities. Railroad maintenance work paid better and was more stable than agricultural labor. Nevertheless, railroad workers had to travel to repair tracks away from their families, who often lived in boxcar communities with few amenities. Factory work was the most desirable option for its high wages, stable employment, and benefits.

47. Maude Swett, Wisconsin Industrial Commission, Milwaukee, in Edson, "Iowa and Wisconsin," Edson Field Reports; Zaragosa Vargas, "Armies in the Fields and Factories: The Mexican Working Classes in the Midwest in the 1920s," Mexican Studies / Estudios Mexicanos 7 (1991), 53, 62; Norris, North for the Harvest, 11.

48. Maude Swett, in Edson, "Iowa and Wisconsin."

49. Perry Beeman, "Families Recall Struggle to Survive in Search for Work," Des Moines Register, 1/16/1985. 
In Iowa, industrial work included manufacturing railroad cars and farm equipment, processing food, and producing cement. ${ }^{50}$

The small-town environment of some Mexican communities undoubtedly appealed to immigrants from rural parts of Mexico who had misgivings about living in congested cities. Mexican immigrants were also attracted to Iowa by the state's lesser racial tensions and better working conditions relative to their experience in midwestern cities or Jim Crow Texas. ${ }^{51}$ It was precisely this racial climate to which the Mexican immigrants alluded in this article's opening vignette. While they encountered discrimination in Iowa, it was not as harsh as in large midwestern cities. Finally, while ethnic enclaves had poor housing and minimal services, they provided a sense of community, comfort, and a refuge that led some families to remain in the state.

AT THE BEGINNING of the twentieth century, employers across the Southwest and Midwest began offering rationales, based on racial stereotypes, to explain their increasing recruitment of and dependence on Mexican immigrant laborers. Employers constructed an image of Mexican workers as docile and hard working to explain their hiring and to justify their exploitation. After passing the so-called quota laws, the U.S. Congress continued to debate whether to extend the quotas to Mexicans. Restrictionists, who characterized Mexicans as belonging to a "degenerate race" that would corrupt the U.S. racial stock and undermine "white" laborers by accepting lower wages, argued in favor of severely limiting Mexican immigration. Anti-restrictionists opposed quotas on Mexican immigrants but racialized them nonetheless, arguing that Mexicans were a "racially degraded labor force" and as such were the ideal agricultural workforce because they were physically suited for stoop labor and, perhaps most importantly,

50. Vargas, "Armies in the Fields and Factories," 56-62, Beeman, "Families Recall Struggle to Survive."

51. Vargas, Proletarians of the North, 17-18. To attract Mexican immigrants, sugar companies in Michigan advertised in Spanish-language newspapers in Texas. Among their promises were free housing, free transportation, garden plots, high wages, and "not [any] trouble getting pay." According to historian Kathleen Mapes, these incentives were meant to contrast a more comfortable life in Michigan to a harsher one in Jim Crow Texas. Mapes, "A Special Class of Labor," 77-78; Fink, Cutting into the Meatpacking Line, 128. 


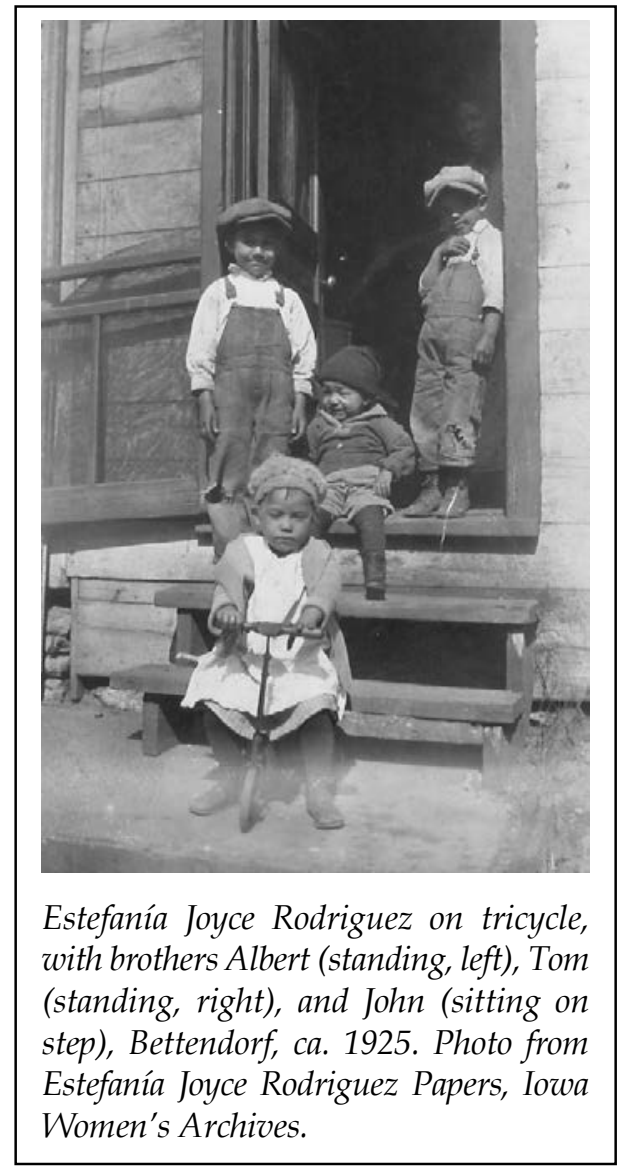

were "homing pigeons" who would "naturally" return to Mexico after the harvests. ${ }^{52}$ The anti-restrictionists' characterization of Mexicans was intended to appease local white residents who feared that "foreign" workers would become permanent settlers in regions where employers increasingly relied on an immigrant labor force.

Responding to the restrictionists, in 1920 U.S. Secretary of Labor William B. Wilson appointed a special commission to study whether Mexican immigrants were competing with white workers for urban jobs. The commission's argument about Mexicans'

52. Mapes, Sweet Tyranny, 145; Mapes, "A Special Class of Labor," 65-68. 
"genetic" disposition to engage in migratory labor epitomized the racialization of these immigrants. According to the commission, "The Mexicans of our day, being descendants of a race in whose veins flow in dominating measure Indian blood, evince the same migratory characteristics that have always been a feature of the Indian race." 53

According to historian David Gutiérrez, employers relied on "Americans' traditional perceptions of Mexicans as an inherently backward, slow, docile, indolent, and tractable people" to argue that "these characteristics constituted the very virtues that made Mexicans an ideal (and cheap) labor force." 54 Reflecting on his company's recruitment of Mexican laborers, Fred Schwartz, an employment manager in Milwaukee, offered a similar characterization: "Usually the Mexicans are appreciative and submissive." 55 Such views were part of a larger pattern in which employers strategically racialized Mexicans as not only "docile" but also "ideally suited" for dangerous work. ${ }^{6}$ Yet these characteristics did not entirely explain the hiring of Mexican immigrants.

Employers racialized Mexican laborers as a separate "race" who could withstand terrible working conditions. Summarizing employers' reasons for hiring Mexican immigrants, a USDL official reported that employers believed that the immigrants, "although not muscularly as strong as northern Europeans nor as active and big, show a greater endurance at work in extreme heat, disagreeable odors and nerve-wracking noises than most other races." 57 Left unmentioned were possible reasons that Mexicans accepted bad working conditions, namely, workers' undocumented status or other obstacles to securing alternate employment as a result of their racialization as unskilled, undependable, and foreign.

Despite Mexican laborers' alleged “docility," employers sought to exert power over these workers by strictly managing

53. Mapes, Sweet Tyranny, 135-36.

54. Gutiérrez, Walls and Mirrors, 46.

55. Fred Schwartz, Employment Manager, Milwaukee, in Edson, "Iowa and Wisconsin."

56. Garcilazo, Traqueros, 49.

57. Edson, "Mexicans in the North Central States," 114. 
their workplaces and housing. In Iowa and elsewhere in the Midwest, railroad companies specifically recruited Mexican immigrants because they could pay them less than white workers and could exert more control over them by providing the only housing option available to them. ${ }^{58} \mathrm{~A}$ distinguishing characteristic that set Mexican immigrant workers in rural areas apart from their counterparts in large midwestern cities was the high level of control exerted by their employers.

This control began with strict labor contracts offered during their recruitment. To recruit laborers, labor contractors who supplied workers to beet growers routinely offered potential workers "free transportation" by railroad. Once at their job destination, however, immigrants discovered that their transportation had not been free; instead, employers deducted its cost from their wages. The labor contracts also allowed employers to garnish a portion of a laborer's wages over several months to hold as security money, which was forfeited if the worker abandoned the job before fulfilling the contract. ${ }^{59}$

Some Mexican immigrants were further dependent on their employers for company-owned housing. The Bettendorf Company, for example, constructed rental housing in Holy City for its laborers, while the Lehigh Portland Company did the same for its workers in Mason City. Immigrants who lived in these ethnic enclaves were aware of the need to maintain good relations with their employers (and landlords) because Mexicans, like African Americans, struggled to find landlords willing to rent to them.

The practice of laying off some workers seasonally added to the employers' power because Mexican immigrants in some Iowa towns could not secure alternative employment. Workers for the Bettendorf Company, for example, had difficulty finding jobs during layoffs because most local employers refused to hire Mexicans, whom they racialized as undesirable and unstable workers. Certainly this practice also occurred in larger midwestern cities,

58. Fink, Cutting into the Meatpacking Line, 123.

59. Valdés, Al Norte, 13-14; García, "Mexican Room," 67; Mapes, "A Special Class of Labor," 77-78. A similar degree of employer control was also found in other agricultural company towns. See José M. Alamillo, Making Lemonade Out of Lemons: Mexican American Labor and Leisure in a California Town, 1880-1960 (Urbana, IL, 2006), 30, 39, 54, 58. 
but immigrant laborers in small towns had greater difficulty securing jobs during layoffs because employment opportunities were more limited. ${ }^{60}$

Railroad companies used several strategies to exert control over Mexican immigrant laborers. Some companies, such as the Santa Fe railroad, preferred recruiting "fresh hands" directly from Mexico over workers who had been in the United States longer. Like other employers, the railroads assumed that recent immigrants were more pliable and less likely to quit their jobs or press for higher wages than those with extensive experience in the U.S. labor force. According to historian Jeffrey Garcilazo, the railroad companies preferred "greenhorns" without track experience because they were less likely to protest their working conditions or complain about overpriced food and low wages. As W. H. Baird, a sugar factory superintendent in Mason City, opined, "Some Mexicans who stay here too long get spoiled." ${ }^{61}$ Railroad companies racialized Mexican immigrants as "docile" and "ideally suited" for difficult and dangerous work (in which laborers sometimes lost limbs). Some employers also stated that they preferred hiring Mexican immigrants rather than African Americans because the Mexicans were less familiar with their labor rights and were more tractable and more willing to accept lower wages. ${ }^{62}$ Justifying his company's recruitment of some 350 Mexican immigrants, an employment manager confirmed this assessment: "We had tried colored men earlier but they gave too much trouble. Therefore, we chose the Mexicans." 63

The Santa Fe and other railroad companies exerted additional control over immigrant laborers by providing their principal source of medical care and transportation. With such a degree of control, railroad companies and other employers had several tools at their disposal to punish recalcitrant workers or to quash

60. García, “Mexican Room,” 67, 97-98; Valdés, Barrios Norteños, 81; Weaver, "From Barrio to 'Boicoteo!'” 218; Edson, "Mexicans in Davenport and Moline"; Fink, Cutting into the Meatpacking Line, 125-26.

61. W. H. Baird, superintendent of sugar factory, Mason City, in Edson, "Iowa and Wisconsin."

62. Garcilazo, Traqueros, 37, 48-49, 61, 118-19; Mapes, Sweet Tyranny, 148-49.

63. Fred Schwartz, Employment Manager, Milwaukee, in Edson, "Iowa and Wisconsin." 
any potential labor organizing by Mexican immigrants. ${ }^{64} \mathrm{~A}$ labor department official observed the high degree of employee supervision in small Iowa towns versus large midwestern cities and concluded that companies used such supervision specifically to prevent labor organizing. ${ }^{65}$ Employers could retaliate by withholding food or medical care or by raising the immigrants' rent. If such measures were not effective, the employers could fire the laborers, who would lose their transportation home and have difficulty finding another job. In 1907, for example, the Santa Fe railroad company not only rejected demands for a wage increase for striking Mexican immigrants in Fort Madison but also refused to provide free transportation back to Mexico, arguing that the workers had broken their contract. 66

IN RESPONSE to employers' controls and racialization, Mexican immigrant workers engaged in subversive practices to carve out some freedom from labor restrictions. They participated in slowdowns, pretended to work, refused to cooperate with foremen, spoke Spanish with one another to avoid foremen's eavesdropping, shared information about other job opportunities, and left their jobs. ${ }^{67}$ Such overt and covert "arts of resistance" were not unique to Mexican immigrants, but rather linked them to other laborers who confronted domination. ${ }^{6}$

One strategy of resistance involved using aliases. While visiting Fort Madison in 1927, USDL official George Edson encountered several men who were using aliases that were known to their immigrant acquaintances. According to Edson, “The father of Francisco and Miguel Reyes, is really Sixto Reyes, but he is working for the Santa Fe railroad here under the name of Macario Pérez." 69 By using an alias, a worker could attempt to find work with higher wages after skipping out on a railroad contract.

64. Fink, Cutting into the Meatpacking Line, 123, 125.

65. Edson, "Mexicans in Mason City," 1927.

66. Sebastián Alvarez interview; "Mexican Contract Laborers Came, Worked and Settled," Fort Madison Daily Democrat, 5/1/1987.

67. Garcilazo, Traqueros, 69.

68. James Scott, Domination and the Arts of Resistance: Hidden Transcripts (New Haven, CT, 1990), 4-5, 198-99.

69. Edson, "Mexicans in Fort Madison." 
In some cases, immigrants found work with the same employer whose contract they had escaped but at a different location from the one stipulated by the contract. ${ }^{70}$ The use of assumed names by newly arrived immigrants demonstrated advanced planning and the influence of extensive social networks because some immigrants had assumed aliases in Mexico even before obtaining a work contract or before arriving in Iowa. In such cases, their transnational and translocal social networks had informed them while they were still in Mexico of the possibilities that an assumed name could open up.

Mexicans were well aware of other employment opportunities within and outside of Iowa. In addition to obtaining job information from Spanish-language newspapers and from word of mouth, they also received direct offers from potential employers. The Santa Fe aggressively recruited Mexican immigrants in El Paso, Texas, where it maintained a recruiting office. Labor contractors based in Topeka, Kansas, traveled to the border city, where they preferred recruiting Mexican immigrants over Mexican Americans. The labor contractors, who spoke Spanish and had experience hiring Mexican laborers, would then accompany the new hires to their destinations. En route to those destinations, immigrants sometimes discovered new employment opportunities through word of mouth, so their initial use of aliases enabled them to skip their contracts (a common practice throughout the United States). ${ }^{71}$ For example, Santiago Salazar, instead of continuing to his contracted destination in Galesburg, Illinois, assumed the alias Santiago Alvarez to abandon his contract in Fort Madison, Iowa, after he encountered friends who informed him of local work with the same railroad company. ${ }^{72}$

Mexican workers were not always the ones who initiated the ruse. Some employers tried to "poach" employees from other jobs. Steel companies in Chicago, for example, attempted to syphon off railroad workers by distributing Spanish-language circulars that offered higher wages and better working conditions. ${ }^{73}$

70. García, “Mexican Room," 66.

71. Edson, "Mexicans in Fort Madison"; Garcilazo, Traqueros, 50.

72. García, "Mexican Room," 66.

73. Edson, "Mexicans in Fort Madison"; Innis-Jiménez, Steel Barrio, 34-35, 40. 
Employers and the public interpreted Mexican immigrants' use of aliases as signs of sketchiness and criminality, another aspect of their racialization. In Fort Madison, one white woman argued that Mexican men used aliases to abandon wives in Mexico and to establish liaisons with other women in the United States. ${ }^{74}$ While some immigrant men might have established such relationships, others had more legitimate reasons for using aliases. Rather than using aliases to hide from their past, Mexican immigrants did so to evade restrictive labor controls in the present. The practice of Mexican contract laborers skipping contracts was widespread throughout the Midwest and the nation as they took active steps to leave unfavorable contracts and destinations. ${ }^{75}$

Mexican immigrants used several other strategies to reclaim some control over their lives from their employers. Unlike immigrants who arrived in the Southwest, newcomers to Iowa in the early twentieth century could not rely on assistance from long-standing Mexican American communities. Most lowa towns lacked large groups of Mexican Americans with U.S. citizenship, knowledge of local laws and customs, and the ability to speak English. In contrast to cities like Los Angeles, Albuquerque, and San Antonio, Iowa towns had few if any community organizations, newspapers, or churches that catered to Mexican Americans and Mexican immigrants. This absence left newly arrived immigrants more vulnerable and more dependent on non-Mexican allies to help them navigate their new surroundings.

While their limited English skills might have circumscribed their options, they learned to rely on key allies for assistance. One type of ally was the padrone - an intermediary between immigrant laborers and local institutions or residents. Some padrones emerged from within the Mexican community after they learned English and adjusted to life in the United States (usually they had lived in the States longer than most other immigrants). José Prado, who had served as president of a mutual aid society called Comisión Honorífica, fulfilled that role in Des Moines. ${ }^{76}$ Elsewhere, Mexicans befriended white residents who spoke Spanish

74. Edson, "Mexicans in Fort Madison"; García, "Mexican Room," 66.

75. García, Mexicans in the Midwest, 7-8; Garcilazo, Traqueros, 37.

76. George T. Edson, “Mexicans in Des Moines, Iowa," Edson Field Reports. 
and could provide assistance. In Council Bluffs and Omaha, Mexicans appealed to Mrs. S. F. Secord, who had served as a missionary in Central America and Mexico. She helped immigrants by acting as an interpreter, and she also translated documents for local businesses. ${ }^{77}$

Although some padrones might have exercised power over immigrants because the workers relied on them for various transactions, others had a more complicated relationship with their immigrant allies. In Fort Madison, a local white woman and grocery store owner, Mrs. W. E. Duffy, served as a padrone for Mexican immigrants, securing medical treatment, navigating local services, and dealing with municipal authorities. Duffy had become a padrone after several Mexican men asked her to be their intermediary and taught her Spanish. Mexican immigrants appealed to "Benita," as they called her, "to call the doctor, priest or undertaker, to arrange for births, marriages and funerals, to talk to lawyers, bankers, and policemen." 78 Through her numerous interactions with immigrants, Duffy learned about illegal activities among immigrants, including serious crimes, but she refused to inform the police because doing so would betray her clients' trust and she would consequently lose her power. According to historian Gunter Peck, Duffy's situation highlighted the workers" "fragile and circumspect" loyalty to her, demonstrating their considerable agency in this padrone relationship. ${ }^{79}$

Mexican immigrants not only depended on transnational social networks to secure employment, but also strengthened such connections through circular migration and remittances. Some employers and local residents preferred that Mexicans return to Mexico after their seasonal employment was complete rather than remain in Iowa as unemployed laborers. These preferences, along with some employers' practice of providing railroad passes for the return trip to Mexico, encouraged the immigrant

77. George T. Edson, "Mexicans in Omaha, Nebraska," Edson Field Reports.

78. Edson, "Mexicans in Fort Madison."

79. Inés García interview; Gunter Peck, “Divided Loyalties: Immigrant Padrones and the Evolution of Industrial Paternalism in North America," International Labor and Working Class History 53 (1998), 51, 54; idem, Reinventing Free Labor: Padrones and Immigrant Workers in the North American West, 1880-1930 (New York, 2000), 154-55. 
pattern of circular migration whereby immigrants returned to their homeland during the winter and journeyed back to Iowa in the spring. Even though the practice of circular migration was encouraged by some employers and white residents, they, in turn, used the practice to racialize Mexicans as "genetically" prone to migration and therefore unreliable as loyal workers.

Some Mexican immigrants left spouses and children back in Mexico. Although the majority of these absent parents were men, some women also entrusted their children to family members back home. Participating in transnational parenthood, these parents had powerful motivations to return to Mexico to visit their children. ${ }^{80}$ In the meantime, they remitted money to their dependent family members. USDL officials estimated that single men allocated approximately 25 percent of their earnings as remittances, while those living with families sent some 10 to 15 percent of their earnings to relatives in Mexico. ${ }^{81}$ This transnational flow of people and money between Mexico and the United States strengthened social and economic networks that fostered community and familial links across the international border, which, in turn, would help future immigrants make the journey north.

Like Mexican immigrants elsewhere in the Midwest, those in Iowa also developed extensive translocal connections. Before arriving in Iowa, some immigrants had a variety of work experiences throughout the Midwest and along the East Coast. Friends and family, who informed the immigrants of employment opportunities, influenced their migration in search of work. Others participated in step migration by living and working in Nebraska, Colorado, Texas, Kansas, and Oklahoma before arriving in Iowa. 82 These patterns of migration within the United States demonstrate that some Mexican immigrants did not arrive in Iowa directly from Mexico and that many laborers moved frequently in search of employment.

80. Pierrette Hondagneu-Sotelo and Ernestine Avila, “'I'm here, but I'm there': The Meanings of Latina Transnational Motherhood," Gender and Society 11 (1997), 548-71.

81. Edson, "Mexicans in the North Central States," 112.

82. Edson, "Mexicans in Davenport and Moline"; Edson, "Mexicans in Omaha." 
The practices of labor recruitment companies contributed to the immigrants' prior work experience. One such company sent workers to the state from various midwestern and southern locations such as Kansas City, Cincinnati, Milwaukee, Chicago, Moline, Rock Island, and Knoxville. The company would target immigrants who could not find jobs in those cities or who had recently been laid off. Among the enticements labor recruiters used were paid transportation and labor contracts that "guaranteed" a wage and a minimum period of work. ${ }^{83}$

In turn, when Iowa employers conducted layoffs, Mexican immigrants often left the state to obtain temporary work elsewhere. Some immigrant laborers would "winter" in Chicago to supplement their income during layoffs from railroad work. For example, workers in Council Bluffs asked for railroad passes to Chicago, Kansas City, and other midwestern cities when they were laid off. ${ }^{84} \mathrm{~A}$ few Spanish-language newspapers aided unemployed workers by identifying companies in the region that were hiring. El Cosmopólita of Kansas City and El Trabajo of Davenport informed readers of the lack of openings throughout the Midwest to discourage immigrants from spending money to travel to a region where work was scarce. ${ }^{85}$ The practice of seasonal migration into and out of the state created and strengthened workers' translocal networks by providing jobs and living experiences in other midwestern locales. Such experiences allowed immigrants to compare work and housing situations, which would influence their future decisions to settle in Iowa or elsewhere.

THE RACIALIZATION OF MEXICANS varied throughout Iowa according to demography, prior immigrant settlement, and the presence of African Americans in each town. Three communities with varying demographic and settlement patterns and, ultimately, different racialization experiences highlight those various experiences. These Mexican enclaves - Bettendorf and Davenport, located along the Mississippi River; Mason City in north

83. Valdés, Al Norte, 12-13.

84 Edson, "Mexicans in Fort Madison"; Edson, "Mexicans in Davenport and Moline"; Edson, "Mexicans in Omaha."

85. García, “Mexican Room,” 65. 
central Iowa; and Fort Madison in southeast Iowa (see map) had similar origins: all three began through the efforts of labor recruiters and then grew through social networks and chain migration. And the Mexican residents of those enclaves did share some common background and experiences. Most Mexican immigrants to these places had traveled directly to Iowa or participated in step migration by stopping to work in Texas before traveling to Iowa. Home ownership was rare; most immigrants were renters or lived in free company housing. Among the homeowners living in these ethnic enclaves, most leased the land from their employer or a private landowner. With the exception of U.S.-born children, the adult Mexican residents had been born in Mexico and very few had become naturalized U.S. citizens or spoke English. This pattern was common across the Midwest and the Southwest as many Mexican immigrants shunned naturalization because of their long-range plans to return to Mexico. ${ }^{86}$ Yet how Mexican immigrants experienced racialization in these communities differed in significant ways.

Bettendorf and Davenport make up the Iowa part of the socalled Quad Cities area (actually consisting of five towns, with Rock Island, East Moline, and Moline on the Illinois side). Mexican immigrants were initially drawn to railroad and foundry jobs in Bettendorf and Davenport in the early twentieth century. These laborers lived in two predominantly Mexican enclaves Holy City in Bettendorf and Cook's Point in Davenport-and also among the general population. The Bettendorf Company created Holy City as an immigrant residential area in the early 1900s, and Cook's Point became a Mexican immigrant enclave in the late 1910s. Initially, Greeks, Serbians, and other Europeans lived in Holy City. By the mid-1920s, however, most Holy City residents were Mexican immigrants, with a few Greeks occupying the better cottages and a few African Americans living in shanties. ${ }^{87}$ By the late 1920s, approximately one-third of the Mexican population of Bettendorf and Davenport lived in Holy City, about a quarter lived in Cook's Point, and the rest resided in

86. Gutiérrez, Walls and Mirrors, 259n26; George J. Sánchez, Becoming Mexican American: Ethnicity, Culture, and Identity in Chicano Los Angeles, 1900-1945 (New York, 1993), 105; Arredondo, Mexican Chicago, 90-93.

87. Edson, "Mexicans in Davenport and Moline." 
rental housing scattered throughout both towns. The 1930 census identifies the majority of Cook's Point residents as Mexicans, with a few European immigrants (mostly Germans) among them. While some African Americans lived in Bettendorf and Davenport, none lived in Cook's Point. Most of the adult Mexican men worked for a railroad company, foundry, or cement factory.

These residential patterns reflected the relatively recent arrival of Mexican immigrants. All but one of the Mexican families in Holy City and Cook's Point rented their homes; the lone homeowner, Lorenzo Hidalgo, had immigrated to the United States in 1912 (earlier than most fellow Mexican immigrants) and presumably bought a home after working in the area longer than his compatriots. Such ethnic enclaves served as a type of linguistic refuge for these monolingual immigrants even though, unlike ethnic enclaves in larger midwestern cities, Holy City and Cook's Point lacked immigrant-owned businesses such as grocery stores.

The majority of Mexican residents of Bettendorf or Davenport who did not live in one of these ethnic enclaves either rented similar housing or lived in boardinghouses elsewhere. George García was the sole homeowner among those who lived outside the Mexican enclaves. A molder at a local foundry, García was married to a white native Iowan and had a family of nine children, all born in Iowa. Another Mexican immigrant, Walter Hernández, also married a white Iowan, became a naturalized citizen, and worked for the Bettendorf Company manufacturing railway cars. ${ }^{88}$ Mexican laborers who worked in the Bettendorf Company's foundry faced occupational segregation, as they could not find employment with other local industries in the Quad Cities.

In contrast to immigrant settlements in the Quad Cities, Mason City was more ethnically diverse and offered a wider variety of employment opportunities. Drawn to jobs on the railroad or in the area's cement factories, sugar beet fields, meatpacking plant, or brick and tile plants, immigrants from various nations settled in a diverse immigrant enclave called Lehigh Row. Most Mexican immigrants worked in the cement and meatpacking

88. Edson, "Mexicans in the North Central States," 99-114; U.S. Bureau of the Census: Fifteenth Census of the United States: 1930, Population Schedule, Scott County, Iowa. Both García and Hernández had stepchildren. Their wives had previously been either widowed or divorced. 


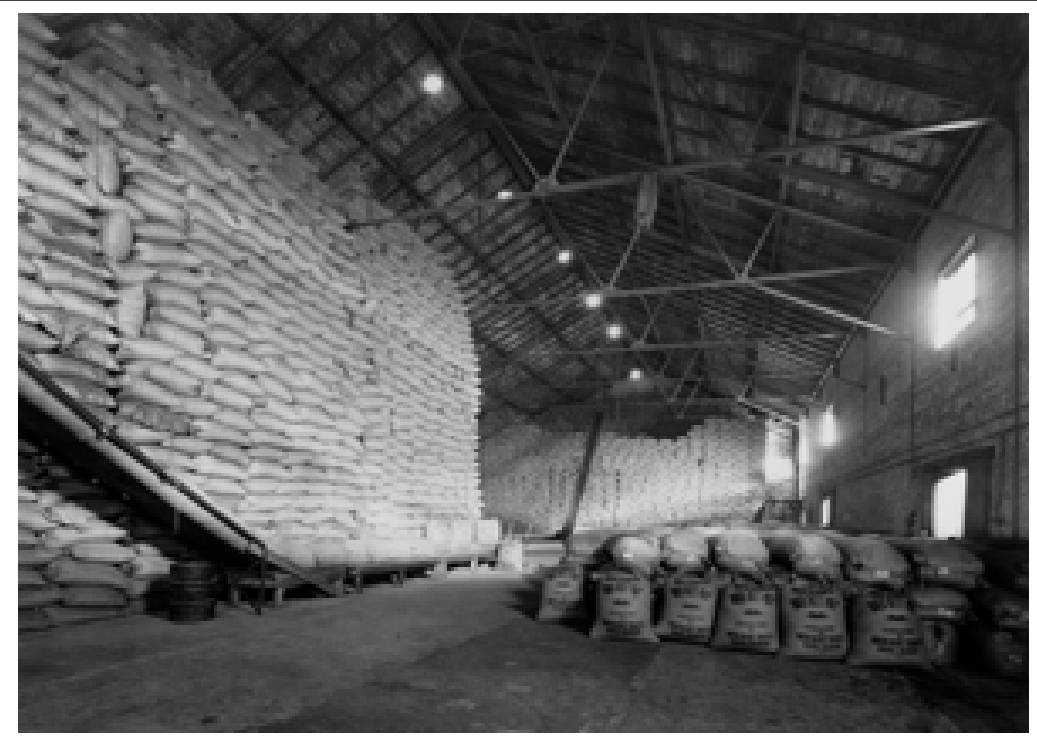

The pulp warehouse of the American Beet Sugar Company in Mason City, ca. 1910-1920. Photo from Agricultural and Natural Resources Archive, Colorado State University, Archives and Special Collections.

industries, although some also labored seasonally for the American Beet Sugar Company.

Lehigh Row emerged as an immigrant enclave in 1911 when the Lehigh Portland Company constructed rental housing for its immigrant workforce. Located on the edge of Mason City, directly across from two cement plants, by 1925 Lehigh Row housed some 400 residents in five rows of two-story duplex houses. Lehigh Row consisted of a mix of southern and eastern European immigrants as well as Mexican immigrants. Relative to their Greek and Italian neighbors, Mexican immigrants had low naturalization rates. In the 1930 census, only Flora Guerra, the wife of a sugar beet laborer from Texas, had become naturalized. ${ }^{89}$

The Mexican residents of Lehigh Row experienced more cross-cultural daily interactions than their counterparts in the

89. Edson, "Mexicans in the North Central States," 104; U.S. Bureau of the Census: Fifteenth Census of the United States: 1930, Population Schedule, Cerro Gordo County, Iowa; Charles M. Meyers, "The Mexican Problem in Mason City," Iowa Journal of History and Politics 27 (1929), 241-43. 


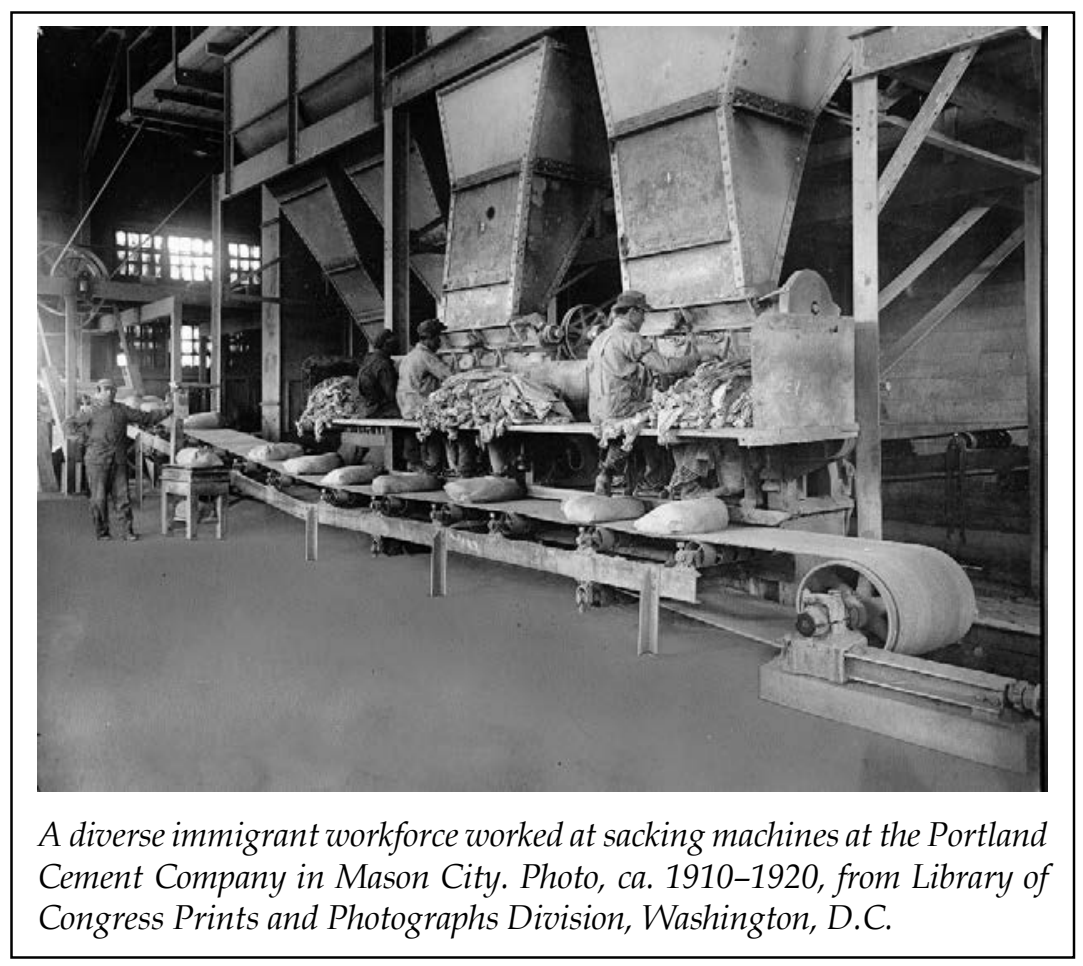

Quad Cities. The majority of the residents of Lehigh Row in Mason City were Greek and Mexican immigrant families, but the enclave was also home to Hungarians, Italians, Montenegrins, and Poles. A small number of African Americans lived in Mason City, but none resided in Lehigh Row. ${ }^{90}$ Several Mexicans who grew up in Mason City remembered interethnic cooperation among the town's immigrant population. Recalling that Greeks and Mexicans got along very well, Patricia Sánchez believed that the immigrant communities bonded because they lived and attended school together, creating frequent interethnic interactions. In her sociological study of Lehigh Row, Helen Karamitros argues that the poverty and isolation shared among southern and eastern European as well as Mexican immigrants led to a strong interethnic community in Mason City. Italian, Mexican, and Polish immigrant residents also shared a common Catholic

90. Karamitros, “Lehigh Row,” 43-49. 
religion and attended the same church built near Lehigh Row. ${ }^{91}$ And unlike some Iowa towns, such as Fort Madison, which segregated Mexican children in "Americanization rooms," Mason City's diverse immigrant population was reflected in its public school classrooms, where recent European immigrants, African Americans, whites, and Mexican immigrants mingled. ${ }^{92}$

Immigrants of different national origins recall a strong sense of community they ascribed to shared living conditions, occupations, and immigrant backgrounds. According to one resident, "There was camaraderie among us Lehigh people.... We played together, shared together, stole together." Another resident offered, "We were kids growing up and didn't care what nationality each other were, what you ate, or how you talked." Many adult immigrants had limited English skills, but they communicated with one another by mixing languages. Referring to this linguistic blending, a Mexican man who grew up in Lehigh Row recalled, "We made up our own language, a mixture of all languages. ... They murdered the English language ... [yet] somehow they all understood each other." According to Peter Vega, immigrant men were more likely to learn English "out of necessity for their jobs," while immigrant women had fewer opportunities if they did not work outside the home. He also recalled a common pattern of English-speaking immigrant children interpreting for their monolingual parents. Italian, Greek, and Mexican children mixed freely, ate at each other's house, and eventually dated one another. Not surprisingly, intermarriage became common among the second generation. ${ }^{93}$

The ethnic diversity of Mason City's neighborhoods and schools led to shared experiences among the immigrant workingclass population. Mexicans and southern and eastern European immigrants often worked and lived together, which could create the impression that, as visiting USDL official George Edson con-

91. Patricia Sánchez interview, 10/26/2006, MLP-IWA; Lupe Dianda interview, 12/9/2006, MLP-IWA; García, “Mexican Room," 71, 76; Karamitros, "Lehigh Row," 43-49, 65, 82-85.

92. Karamitros, "Lehigh Row," 76-85; García, "Mexican Room," 71.

93. Karamitros, "Lehigh Row," 66, 57, 75-76; "Lehigh Row Remembered"; Patricia Sánchez interview, 10/26/2006, MLP-IWA; Lupe Dianda interview, 12/9/ 2006, MLP-IWA. 
cluded in the late 1920s, "discrimination is not so noticeable." Immigrants in Lehigh Row themselves recalled a feeling of camaraderie among fellow immigrants regardless of their background. According to one resident, "Mexicans had their culture, Greeks had theirs, Italian theirs, but it didn't matter. Because every culture was good and everyone was for the family.... We played together, we protected each other. Good values. We all stuck together." 94

Yet, despite Mason City's diverse population, its residents made clear distinctions between recent immigrants and the nativeborn white population, and those distinctions also contributed to the sense of community among the immigrant groups of southern and eastern Europeans as well as Mexicans. Several residents of Lehigh Row confirmed that native-born white Iowans did not accept southern and eastern European and Mexican immigrants as equals. A second-generation Italian immigrant recalled her experience. "We felt ignored. It affected what I thought of my Italian heritage, when I was younger. . . . The foreign people didn't have a chance here in Mason City." Similarly, a Greek immigrant remembered feeling ostracized by her classmates. "Not everyone was tolerant. ... Some of the girls at Lincoln school tormented me. ... The message was, 'You' re not American,' but damn it all, we were American!" 95 According to historians James Barrett and David Roediger, a sense of common grievances sometimes led southern and eastern Europeans, characterized as "inbetween peoples" (located between white and black people), to ally with non-whites. 96

94. Edson, "Mexicans in Mason City"; Karamitros, "Lehigh Row," 66; García, "Mexican Room," 71.

95. Quotes from Karamitros, “Lehigh Row," 66, 77. See also García, “Mexican Room," 71.

96. James R. Barrett and David Roediger, "Inbetween Peoples: Race, Nationality and the 'New' Immigrant Working Class," Journal of American Ethnic History 16 (1997), 28. During this period, the general U.S. public viewed southern and eastern Europeans as "foreigners," yet distinguished them from African Americans, Asian immigrants, and Mexicans. Southern and eastern Europeans held an ambiguous racial status. White Americans considered some immigrants (Greeks, Italians, etc.) variously as non-whites, less-than-whites, and "not-yet-white" ethnics. Higbie, "Rural Work, Household Subsistence, and the North American Working Class," 59; Barrett and Roediger, "Inbetween Peoples," 7-9. The U.S. public's views about southern and eastern Europeans led the U.S. Congress to 
In addition to the discrimination that all new immigrant groups shared, Mexicans faced additional obstacles. Iowa's white residents racialized Mexican immigrants as inferior non-whites with deficient morals. While discussing ethnic relations, white residents cited several examples of Mexicans intermarrying or "mixing" with southern and eastern European immigrant women or African American women but very rarely with white midwesterners. Several white residents also noted that Mexicans shared housing with and patronized businesses owned by southern and eastern Europeans.

Not surprisingly, white residents tended to distance themselves from American Indians, African Americans, and Mexicans, but did not necessarily rule out intermarriage with southern and eastern Europeans. In contrast, some white residents expressed strong opposition to intermarriage with Mexicans. Such opposition was grounded in a belief in racial hierarchies. "There will surely be intermarriage," concluded a white woman in Mason City, "but the Mexicans are most inferior." 97

Among the white Iowans who racialized Mexican immigrants were officials who enforced social policies that affected immigrants. "I would hate to see any of my children marry persons with even 1/100 part of Negro, Mexican or Indian blood," argued the superintendent of schools in nearby Britt, Iowa, "and I believe that the community feels the same way." 98 In voicing their opposition to intermarriage and grouping Mexicans along with American

pass immigration restrictions during the 1920s. Those quotas, however, did not apply to immigrants (including Mexicans) from the Western Hemisphere as a result of vigorous lobbying efforts from agricultural and industrial employers who had grown dependent on Mexican immigrant laborers. White Iowans' views towards immigrants were part of a national discussion on restricting immigration that was based on pseudoscientific ideas about racial hierarchies. Those racial hierarchies placed northern and western Europeans above southern and eastern Europeans, with American Indians, Asian Americans, African Americans, and Latinos at the bottom. Spickard, Almost All Aliens, 262-73, 27789; Barrett and Roediger, "Inbetween Peoples," 4-6.

97. Eva Gibbs, County Charities, Mason City, quoted in Edson, "Iowa and Wisconsin."

98. C. E. Cooper, Superintendent of Schools, Britt, Iowa, quoted in Edson, "Iowa and Wisconsin." That same school superintendent labeled Mexican school children as "retarded" because absences caused them to fall behind in school, and he noted that most Mexican students were not expected to continue into high school. 
Indians and African Americans as racial others, white residents revealed their racialization of Mexicans as "non-whites." 99

Other officials added harsh characterizations to the racialization of Mexicans. Eva Gibbs, a Mason City charity worker, addressed the supposed lower values and inferiority of Mexicans in blunt language. She complained that Mexican immigrants did not know how to live in a cold climate, had poor diets, were infected with syphilis, and lived in overcrowded conditions (without acknowledging their poverty or the local community's restrictions on Mexicans). She alleged that Mexican parents chose to buy new Ford vehicles with their earnings while their children attended school barefoot. Alluding to the 1920s quota laws, Gibbs asked, "Why should we prevent good [Russian-]German or Greek women from coming to this country? They are better than the miserable, dirty, [and] nasty Mexicans as they are many times." She acknowledged that very little charity was offered to Mexicans (less than $\$ 150$ for the entire winter) and that they were not referred to the hospital because "we don't like to fill up our state hospital with Mexicans." Finally, she noted that the "Americanization" of Mexicans was failing because the county did not devote enough resources to the task. Not surprisingly, she also criminalized Mexicans by associating them with "bootlegging." Gibbs's views were shared by some employers, merchants, and journalists who not only criminalized Mexicans but also blamed them for spreading infectious diseases. ${ }^{100}$

99. Natalia Molina, “'In a Race All Their Own': The Quest to Make Mexicans Ineligible for U.S. Citizenship," Pacific Historical Review 79 (2010), 168-69.

100. Eva Gibbs, County Charities, Mason City, in Edson, "Iowa and Wisconsin." Among white midwesterners, it was common to associate Mexicans with various types of criminal activity. Local newspapers helped shape white residents' views, and their coverage of Mexican communities was often limited to details of crimes, industrial accidents, or infectious diseases involving Mexican immigrants. See Valdes, Barrios Norteños, 59. Examples of newspaper coverage of crimes involving Mexicans include Marshalltown Evening Times-Republican, 8/17/1916, 9/22/1917; The Bystander, 3/2/1917; and Keokuk Daily Gate City and Constitution-Democrat, 1/29/1919. On fears that Mexican immigrants might have introduced typhus to Iowa, see Marshalltown Evening Times-Republican, 11/20/1916 and 12/6/1916. Some northern Iowa residents portrayed Mexicans as marijuana users, bootleggers, and drunks, while local merchants characterized them as shoplifters. Residents also accused Mexicans of being prone to violence. Meyers, "The Mexican Problem in Mason City," 238, 240-41; Edson, "Mexicans in the North Central States," 114. 
As a charity worker, Gibbs was undoubtedly aware of immigrants' needs and of white residents' reactions to their plight. She was one of several white residents who characterized Mexicans as inferior racial others who were less desirable than southern and eastern Europeans. Ultimately, the negative views held by education and social service officials created significant obstacles for Mexican immigrants as they attempted to adjust to life in Iowa.

The Mexican immigrant communities in Fort Madison offered a third pattern of employment opportunities, cross-cultural interactions, and racialization. Drawn to jobs with the Santa Fe railroad, Mexican immigrants established three settlements on land owned by the railroad. ${ }^{101}$ By the late 1910s, three "barrios" (Mexican ethnic enclaves) - La Yarda, El Istafiate, and El Cometaexisted in the unincorporated land known as Shopton. Like other ethnic enclaves, these three barrios were located near the immigrants' workplace, which included the Santa Fe roundhouse and maintenance yards. Immigrants lived in boxcars or shanties constructed from discarded railroad materials. In the mid-1920s, some 500 Mexican immigrants lived in Fort Madison. Non-Mexicans rarely visited these three barrios, one of which was described as a "jungle village," "a place where few outsiders ventured." Such racialization of barrios characterized the settlements as dangerous and unkempt places inhabited by "foreigners." 102

In 1926 a flood resulted in the closing of El Cometa after residents were informed that they could no longer live in the floodprone area. Some displaced residents found housing in the other two barrios, but a group of 76 immigrants sought to purchase land elsewhere in Fort Madison. After locating a landowner willing to sell two blocks of land, the group of displaced immigrants ran into a problem when a mob of white residents, who lived near the property for sale threatened the landowner. The mob, organized by white women, told the landowner that "if he sold to the Mexicans and they built homes there, they would stone them out or burn their houses." Faced with such strident opposition, the Mexican families declined to buy the two-block parcel. They eventually purchased two separate lots in Fort Madison, where they

101. Benita Aguirre interview; Inés García interview.

102. Edson, "Mexicans in Fort Madison." 
built a range of houses, including small huts costing $\$ 75$, larger homes valued at over $\$ 800$, and a few stores. ${ }^{103}$

The outright hostility exhibited in this case was but one example of a harsher pattern of segregation in Fort Madison than in other eastern Iowa settlements. In Fort Madison, whites' racialization of Mexicans included portraying them as unwanted neighbors. Not surprisingly, Lucy Prado and Inés García, who grew up in Fort Madison, recalled few interactions with whites outside of school. 104

The type of jobs typically held by Mexican laborers in Fort Madison contributed to their isolation. Industrial employers used segregated work gangs, composed exclusively of Mexicans, to undermine unionization efforts, depress wages, and increase productivity through competition. ${ }^{105}$ Sebastián Alvarez, who lived in Fort Madison, recalls segregated railroad crews (Mexicans, whites, and African Americans) in which supervisors were occasionally white but the rest of the crew were Mexicans. According to Alvarez, "On a section they were all Mexican people. You couldn't see a white guy hardly, maybe the foreman was white, or the second in command. But all of "em were Mexican." The men who worked in segregated railroad gangs were given the lowest-paid and most dangerous work assignments. ${ }^{106}$ Employers and foremen racialized dangerous railroad work as labor for Mexicans or African Americans. Like African American railroad workers, Mexicans were initially not allowed to join unions. ${ }^{107}$ Moreover, despite years of service, railroad workers often witnessed less-skilled white counterparts receive promotions over Mexican immigrants. Living in company-owned housing populated almost exclusively by fellow compatriots further segregated some workers. But the isolation of living in ethnic enclaves was most pronounced for those women who did not work outside the home and who lived in predominantly Mexican communities.

103. Ibid.

104. Ibid.; Inés García interview; Lucy Prado interview, 12/22/2005, MLP-IWA. 105. Garcilazo, Traqueros, 32-33; Barrett and Roediger, "Inbetween Peoples," 16. 106. Sebastián Alvarez interview; García, “Mexican Room,” 97-98.

107. Fink, Cutting into the Meatpacking Line, 125-26. According to Sebastián Alvarez, he joined a railroad union in 1940. Sebastián Alvarez interview. 
Mexican immigrants in Fort Madison experienced other forms of discrimination in addition to residential and workplace segregation. Mexicans had to sit in the back of the local Catholic church and receive mass in the basement of a Catholic school. ${ }^{108}$ That school basement was also the setting for several Mexican immigrant weddings because couples were not allowed to marry in the main sanctuary. At local movie theaters, residents expected Mexicans to sit in the back seats of the balcony. Benita Aguirre remembers that local residents "were very prejudiced" and cast disapproving looks at Mexican children who strayed from local conventions regarding seating in the theater. "You couldn't go anywhere to eat," recalled Aguirre. "They wouldn't allow you." Sebastián Alvarez agreed that Mexican immigrants faced considerable discrimination in Fort Madison, where local restaurants, taverns, and barbershops refused to serve them. But perhaps the most lasting form of segregation took place in the public schools, where Mexican schoolchildren were placed in "Americanization rooms," also called "Mexican rooms." In the early 1920s the Richardson public school began segregating Mexican children into a separate room, and in 1930, in response to protests from white parents, that school created a separate building for Mexican schoolchildren. Even Iowans elsewhere noted in 1920 that Fort Madison had a "real Mexican problem" and that it wanted to get rid of Mexican immigrants who had been recruited by the Santa Fe railroad during World War I. ${ }^{109}$

While Mexicans in Fort Madison had few interactions with white residents, they seem to have had more alliances with African Americans than their compatriots in other Iowa towns did. By the mid-1920s, several Mexican men had intermarried with African American women in Fort Madison. Longtime Mexican residents recalled living next door to African Americans, sharing food as neighbors, and generally having friendly interactions in the 1920s and 1930s. ${ }^{110}$ In the Quad Cities area, some Mexicans

108. Lucy Prado interview.

109. Benita Aguirre interview; Sebastián Alvarez interview; García, "Mexican Room," 97-100; Denison Review, 2/18/1920.

110. A few Mexican men also married white women, but it is unclear if these women were originally from Fort Madison. Edson, "Mexicans in Fort Madison"; Inés García interview; Sebastián Alvarez interview. 
and African Americans were neighbors and shared similar labor experiences, but none intermarried. Edson, the visiting USDL official, observed that Mexicans in Davenport felt some ostracism from southern and eastern European immigrants; he believed that experience might have led them to feel an affinity with African Americans. In turn, Mexicans' alliances and friendships with African Americans might have reinforced the racialization of both groups by Fort Madison's white residents. Friendships between Mexican immigrants and African Americans were less common elsewhere in the state. For example, Mexican immigrants in Manly appear to have made a conscious effort to prevent African Americans from becoming their neighbors. Like Mexican immigrants in Chicago during the same period, the Mexicans in Manly attempted to separate themselves from African Americans to avoid being marked as "black" in a society where such a racial position was a big disadvantage. ${ }^{111}$

To confront their racialization, Mexicans developed several strategies that varied by location. In Fort Madison, one of the most significant alliances developed between the Mexican community and Harry Harper, an African American doctor. Harper provided medical services to Mexicans, learned fluent Spanish to serve them better, and in the process developed a strong affinity for their struggles. That relationship was mutually beneficial as Mexican immigrants obtained medical care, while Harper secured patients (albeit poor ones) in a town in which initially landlords refused to rent him office space, the white medical community offered him limited acceptance, and white residents avoided visiting an African American doctor. As he did for African American residents, Harper assisted Mexicans struggling against local discriminatory practices. At the request of Mexican parents in 1930, he became involved in opposing a Fort Madison school board plan to segregate Mexican and African American schoolchildren. Despite these efforts, the school board eventually built a separate building to house the "Americanization room" or "Mexican room," where some Mexican children received instruction. ${ }^{112}$

111. Edson, "Mexicans in Davenport and Moline"; George T. Edson, "Mexicans in Manly, Iowa," Edson Field Reports; Arredondo, Mexican Chicago, 76-79.

112. Steven Berry, M.D., and Erin Herndon, M.D., "Healing Hands, Questing Hearts: African-American Physicians in Iowa," in Outside In: African American 


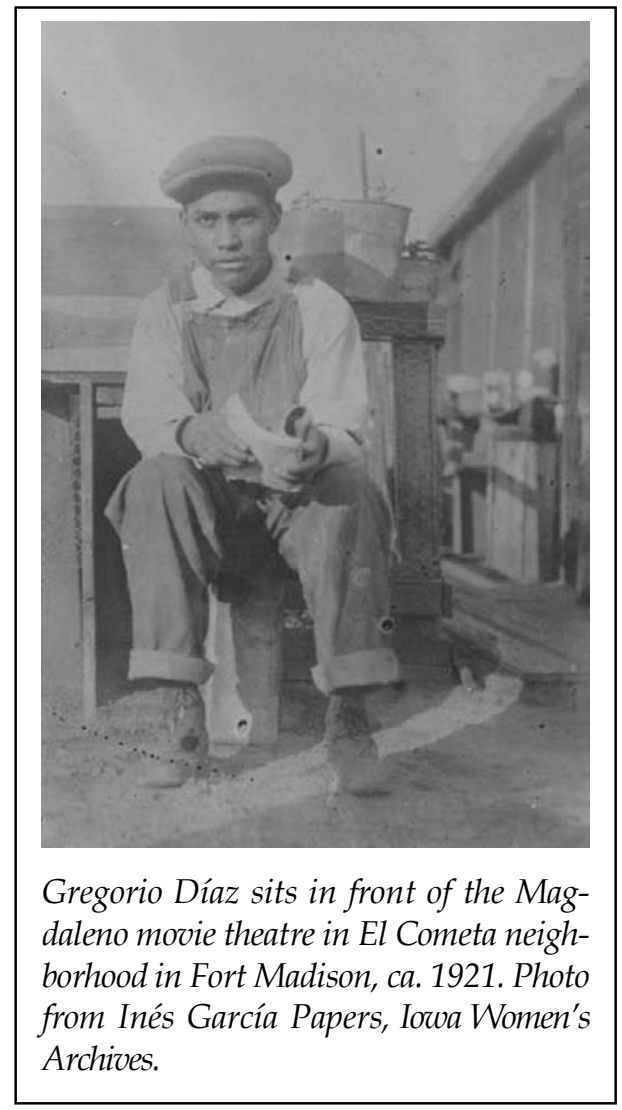

In addition to enforcing segregated public facilities, Fort Madison's white residents also appear to have shared a view of the expected occupations for African American and Mexican women. Several Mexican American women recalled not securing office and restaurant jobs to which they applied but instead being offered work as domestics in white residents' homes. School officials also limited Mexicans' occupational prospects. After several students from Fort Madison High School applied for internships at Sheaffer Pen Company, the positions were given to white students while the Mexican students were offered jobs involving baby-sitting, washing windows, or ironing clothes in

History in Iowa, 1838-2000, ed. Bill Silag (Des Moines, 2001), 256; García, "Mexican Room," 98-99. 
white residents' homes. ${ }^{113}$ The reactions and views of these white residents were undoubtedly influenced by Mexicans' interactions and alliances with African Americans. Their previous experience with and views of African Americans shaped the racial scripts that whites then used to categorize and interact with Mexican immigrants, who were relative newcomers to the state. Not surprisingly, white Iowans racialized domestic and service work as labor limited to Mexicans and African Americans.

MEXICAN IMMIGRANTS in northern and eastern Iowa experienced different racialization processes than those in other midwestern locations or in the American Southwest. Historian Dennis Valdés summarizes studies of Mexicans in the Midwest by listing several general characteristics: laborers first visited the region as sojourners but began settling in the Midwest during the 1910s and 1920s; most were unskilled workers who found employment in agriculture and in the railroad and cement industries; and the immigrants looked to Mexico rather than the American Southwest as a homeland. ${ }^{114}$ These patterns accurately describe Iowa's Mexican immigrants.

Valdés also argues that a black-white cultural dichotomy rather than a Mexican-Anglo division shaped Mexican immigrants' racial experience in the Midwest. ${ }^{115}$ That might hold true in Minneapolis, Chicago, and Detroit, but it does not apply to cities and towns in Iowa with much smaller African American populations. In Iowa, Mexicans' racial experience was most often influenced by the local population's previous perception of and interactions with southern and eastern Europeans who often labored alongside the Mexican newcomers. One clear exception was Fort Madison, where white residents tended to group Mexicans and African Americans together as racial others. White Iowans used the racial scripts they had created for southern and eastern Europeans as well as for African Americans to racialize Mexican immigrants, with whom whites had less experience. White Iowans' use of racial scripts was part of a larger national pattern during

113. Inés García interview; García, “Mexican Room,” 100-101.

114. Valdés, Barrios Norteños, 22-27.

115. Ibid., 19-20 
the 1920s in which white Americans frequently compared Mexicans to other racialized groups. 116 Geography, local power relations, and Mexican immigrants' interethnic interactions with other non-dominant populations shaped these racial scripts. Finally, the degree of employers' control over Mexican immigrant laborers in Iowa also distinguished their experience from that of their counterparts in larger midwestern cities.

The small population of Mexican immigrants in Iowa partly explains their distinctive experience. Their ethnic enclaves functioned less as sites of cultural renewal than as communities that offered refuge from the dominant society. Mexicans' relatively low population numbers motivated some to create cross-cultural alliances with southern and eastern European immigrants or with African Americans (in towns such as Fort Madison), who also had low population numbers in the state. Because many Mexican immigrants lived in ethnic enclaves relatively isolated from the state's other residents and because the Mexican population remained small, white residents did not perceive them as much of a threat. These factors might explain why Iowa's response during the Great Depression differed from neighboring states that launched forced repatriation campaigns directed at Mexican newcomers. Although unemployment and the general scarcity of the Great Depression motivated some to voluntarily return to Mexico, Mexican immigrants in Iowa were not subject to official deportation efforts. ${ }^{117}$ Mexican immigrants' dependence on cross-cultural interactions distinguished their experiences in Iowa from those of their counterparts in the American Southwest and in larger midwestern cities.

116. Molina, "The Power of Racial Scripts," 163-69.

117. Valdés, Barrios Norteños, 87-100; Guerin-Gonzales, Mexican Workers and American Dreams, 100; Weaver, "From Barrio to 'Boicoteo!," 220; García, "Mexican Room," 102. According to Norris, North for the Harvest, 43, "Some evidence suggests that sugar beet companies throughout the Midwest and Great Lakes tried to shield their workers [from official deportation campaigns]." 